\title{
Ergenlerde Algılanan Anne Baba Davranışlarıyla Akran İlişkileri Arasında Özerkliğin Aracı Rolü ${ }^{1}$
}

\author{
DOI: 10.26466/opus.804045
}

\author{
* \\ Fatma Akın Gökalp* - Mehmet Murat ** \\ * Psikolojik Danışman, Şehit Ercan Hırçın Ortaokulu, Karabük/Türkiye \\ E-Posta: fatma.f94@gmail.com \\ ORCID: 0000-0001-8828-1924 \\ ** Doç. Dr, Gaziantep Üniversitesi, Eğitim Fakültesi, Gaziantep/Türkiye \\ E-Posta: mmurat6147@gmail.com \\ ORCID: 0000-0003-3946-7006
}

\begin{abstract}
Öz
Araştırmanın amacl, ergenlerde algılanan anne baba davranışlarıla akran ilişkileri arasında özerkliğin aracı rolünün incelenmesidir. Araştırmada ilişkisel tarama modeli kullanılmıştır. Araştırma katılımcılarımı Gaziantep ilinin Şehitkamil ilçesinde fen, anadolu ve meslek liselerinde öğrenim gören 444' ü erkek, 519' u kadın toplam 963 ergen oluşturmaktadır. Araştırma verilerinin toplanmasında 'Akran İlişkileri Ölçeğii', 'Leuven Algilanan Ana Babalık/Ergen Sürümü Ölçeği', 'Ergen Özerklik Ölçeği' ve araştırmacı tarafından hazırlanan 'Kişisel Bilgi Formu' kullanılmıştır. Verilerin analizi SPSS 21 paket programı ve AMOS 22.0 programı aracılığıyla gerçekleştirilmiştir. Araştırmanın amaçlarını test etmek üzere Pearson Momentlar Çarpımı Korelasyonu ve Yapısal Eşitlik Modeli kullanılmıştır.Ergenlerde algılanan anne baba davranışlarıyla akran ilişkileri arasında özerkliğin aracı rolü olup olmadığı anne ve baba için ayrı ayr modellerde yapısal eşitlik modeliyle test edilmiştir. Araştırma sonucunda hem anne hem baba davranışlar ile akran ilişkileri arasında özerkliğin kısmi aracı rol oynadığı bulunmuştur. Kısmı aracılığın anlamlılığına ek kanıt olarak Bootstrapping ve Sobel testi kullanışmıştır. Her iki analiz sonucunda, kısmi aracılın anlamlı olduğu sonucuna ulaşılmıştır. Araştırma sonuçları alanyazındaki başka araştırma sonuçlarıyla tartışılmış ve öneriler sunulmuştur.
\end{abstract}

Anahtar Kelimeler: Ergen, Algılanan Anne Baba Davranışları, Özerklik, Akran İlişkisi

\footnotetext{
${ }^{1}$ Bu makale Doç. Dr. Mehmet MURAT danışmanlığında yürütülen "Ergenlerde Algılanan Anne Baba Davranışlarıyla Akran Iliş̧kileri Arasında Özerkliğin Aracı Rolü" başlıklı yüksek lisans tezinden üretilmiştir.
} 


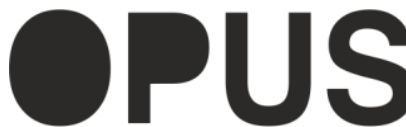

Uluslararası Toplum Araştırmaları Dergisi International Journal of Society Researches
E-ISSN : 2528-9535

YIl Year: 10

Cilt Volume: 16

Sayı Issue :Eğitim ve Toplum Özel Sayısı

Aralık December 2020

Makalenin Geliș Tarihi Received Date: 01/10/2020

Makalenin Kabul Tarihi Accepted Date: 29/12/2020

\title{
The Mediating Role Of Autonomy Between Perceived Parent Behavior And Peer Relationships In Adolescents
}

\begin{abstract}
The aim of the study is to examine the role of autonomy as an intermediary between perceived parent behavior and peer relationships in adolescents. Relational scanning model was used in the research. The participants of the research were 444 male and 519 female adolescents who were educated in science, Anatolian and vocational high schools in Şehitkamil district of Gaziantep province. 'Peer Relationships Scale', 'Leuven Perceived Parenting /Adolescent Version Scale', 'Adolescent Autonomy Scale' and a Personal Information Form prepared by researcher were used in the collection of research data. The analysis of the data was carried out through the SPSS 21 package program and the AMOS 22.0 program. Pearson moments multiplication correlation and structural equality model were used to test the objectives of the study. Whether autonomy had a mediating role between perceived parental behaviors and peer relationships in adolescents was tested with structural equation model in separate models for mothers and fathers. As a result of the research, it was found that autonomy played a partial mediating role between both mother and father behaviors and peer relationships. Bootstrapping and Sobel tests were used as additional evidence for the significance of partial mediation. As a result of both analyzes, it was concluded that partial mediation was significant. Research results were discussed with other research results in the literature and recommendations were presented.
\end{abstract}

Keywords: Adolescent, Perceived Parenting Behavior, Autonomy, Peer Relationship 


\section{Giriş}

Ergenlik bedensel, toplumsal ve bilişsel olgunlaşma dönemidir (Gander ve Gardiner, 2010). Bu dönemde yaşanan deneyimler, ergenin yaşamına önemli katkı sağlamakla birlikte, ergenin kimliğinin oluştuğu bu süreç ergen için zor olabilmektedir. Ergenin yakın çevresini oluşturan ebeveyn ve akranlarıyla kurduğu ilişki, sürecin başarıyla atlatılmasına yardımcı olmaktadır.

Ergen bu dönemde kendisinde meydana gelen fizyolojik ve psiko-sosyal değişimlere uyum sağlamaya çalışırken, tutum ve davranışlarını örnek alacağı, özdeşim kurabileceği bireylere yani anne babasına ihtiyaç duyar (Kulaksızoğlu, 2004). Ebeveynler, ergenin zihinsel ve sosyal becerileri ile kişilerarası ilişkilerdeki duygusal tepkilerine ilişkin farkındalık kazanmalarında rol oynayan çevresel faktörlerin başında gelmektedir. Sistem olarak ailede tüm bireyler birbiriyle ve aile bütünüyle devamlı etkileşim halindedir. Aile içerisindeki bireylerin yanında aile dışındaki bireylerin davranışlarının da ailenin tüm bireylerinde ve aile işleyişinde etkisi olacaktır. Böyle bir yapıdan bireyi ayırarak anlamaya çalısmak gerçekçi değildir (Gladding, 2011). Bu nedenle aile ortamındaki yaşantılar, karşılaşılan tutum ve davranışlar bireyin gelişimiyle karşılıklı bir etkileşim halindedir.

Ergenlik döneminde bireyin oluşturduğu davranış kalıpları, geliştirdiği sosyal beceriler, ergenin kendisini kabul düzeyi, ebeveyn ve arkadaşlık ilişkileri ve ergenin sağlıklı özerklik geliştirmesi önemlidir. Ergenlik döneminde çocuk ve ebeveynin öncelikleri ve bakış açları farklılaşmaya başlamaktadır. Bunun yanında her konuda deneyimli olmayan ergen onlardan bağımsızlaşmak ister ancak bir taraftan da onlar tarafından anlaşılmaya ve desteklenmeye ihtiyaç duymaktadır (Gültekin ve Baran, 2007; Atalay, 2018). Bununla birlikte ergenlikte akranlarla etkileşim giderek artmakta ve akran grubu tarafından onaylanmak ve kabul görmek güçlü hale gelmeye başlamaktadır (Kaner, 2000). Ergen bir grubun parçası olmaya yönelik çok fazla fedakarlıkta bulunup enerjisinin çoğunu arkadaşlık kurmaya harcamaktadir.

Ergenlik döneminde ebeveynin anne baba yaklaşımları ve ergenin arkadaşlıkları arasındaki ilişkiler karmaşık ve dinamik bir süreçtir. Birbirlerini etkileyen bu iki yapının ergen için benzer önemde olduğunu gösteren çalışmalar bulunmaktadır. Yapılan bir çalışmada, ergenlerden duygusal destek ve yakınlık figürlerini belirtmeleri istenmiş, ergenlerin ebeveyn ve ak- 
ranlarını eşit sayıda aday gösterdiği bulunmuştur (Freeman 1997; Akt. Bayraktar, 2007). Akranlar da aile gibi çocuğun kişiliğinin oluşmasında, gelişiminde ve sosyalleşmesinde oldukça önemlidir. Harry Stack Sullivan ergen arkadaşlıkları çalışmalarında en etkili kuramcı olmuştur. Sullivan'a göre ergenlik boyunca, sosyal ihtiyaçların karşılanmasında arkadaşlık giderek daha önemli hale gelmektedir. Sullivan, özellikle erken ergenlik boyunca yakınlık ihtiyacının yoğunlaştığını, bunun ergenleri arkadaş bulmak için güdümlediğini savunmaktadır. Ergenler yakın arkadaşlık kurmakta başarısız olurlarsa, yalnızlık yaşarlar ve öz değer duyguları azalır (Santrock, 2017). Bu bağlamda ergenlikte sağlıklı ve yapıcı arkadaşlık kurabilmek ve devamlılı̆̆ını sağlamak başı başına bir başarıdır.

Ergenin kazanması gereken önemli bir beceri de özerkliktir. Ergenin, ebeveynlerinden uzaklaşarak arkadaşlık ilişkilerinin önemli hale gelmesi özerklik ihtiyacı ile bağlantılıdır. Ebeveyn ve ergenlerin algısına göre, ebeveynlerin ergenin bazı seçimleri üzerinde yetki düzeyleri incelenen çalışmalarda (Smetana, 2008), hem ebeveyn hem de ergenlerin, ebeveynlerin daha fazla yetkili algılandığı ahlaki, dini ve eğitim alanlarının tam tersine akran ilişkilerinde, seçimlerini zorla kabul ettirmeye yetkili olmadığı alanlar olarak algıladıkları ortaya konulmuştur. Bu durum ergenin özerkliğinin bir yansıması olarak değerlendirilebilir. Çünkü ergenin kendisini yetkin olarak algıladığı arkadaşlık ilişkileri, birçok alanda olan ebeveyn yetkisinin olmadığ 1 bir alan olarak ortaya çıkmaktadır.

Psikososyal gelişim rollerinin yanında yetişkin rollerine hazırlık süreci olan ergenliğin en belirleyici özelliklerinden biri kimlik arayışıdır. Kimlik gelişimi diğerleriyle iletişim ve etkileşim ile bağlantılı olması nedeniyle, anne baba davranışları ve akran ilişkilerinden bağımsız olması düşünülemez. Bütüncül psikoterapi bakış açısıyla psiko-toplumsal kimlik gelişiminin basamakları arasında özerklik ve arkadaş ilişkilerinin önemli yer tuttuğu ve kimlik oluşumunun her aşamasında ebeveyn davranışları ve desteğinin önemli bir faktör olduğu belirtilmektedir (Özakkaş, 2015). Birey bağımsızlığını ve kişisel kimlik duygusunu kazandığında ergenlik dönemi sona ermektedir (Derman, 2008; Koç, 2019). Özerklik, ebeveyn ve arkadaşlarla olan ilişkilerin önemli psikososyal gelişim özellikleri arasında yer alması, kimlik gelişimi üzerinde önemli etkilerinin olması açısından üç değişken birlikte ergenliğin önemli bir yönünü oluşturmaktadır. 
Anne baba tutumları bireyin sosyalleşmesini etkileyen en temel faktörlerden biridir (Kulaksızoğlu, 2004; Damarll, 2006). Alanyazın incelendiğinde, çalışmalarda akran ilişkilerini etkilediği düşünülen ana baba tutumları üzerinde durulmaktadır (Curtner-Smith ve MacKinnon, 1994; Ladd ve Ladd, 1998; Akgün, 2005; Şirvanl1-Özen, 2006; Soenens, Vansteenkiste, Smits, Lowet ve Goossens, 2007; Totan ve Yöndem, 2007; Cook, Buehler ve Fletcher, 2012). Anne babanın yaklaşımı, ergenin kişiliği ve duygusal yaşantısıyla birlikte arkadaş ilişkilerini de etkilemektedir (Yaban, Sayıl ve Kındap Tepe, 2013). Sosyal davranışların birçoğu anne ve babadan öğrenilmekte, bu davranışlar yoluyla da arkadaşlarla etkileşime geçilmektedir (Bandura, 1977). Öğrenilmiş destekleyici davranışlar ile arkadaşlıklardan alınan doyum pozitif ilişkili, saldırgan davranışlar ile arkadaşlıkların niteliğinin negatif ilişkili olduğu belirtilmektedir (Cui, Conger, Bryant ve Elder, 2002). Bunun yanında ebeveynlerin demokratik, otoriter veya aşırı koruyucu davranması çocuğun farklı sosyal davranışlar geliştirmesini sağlayacaktır (Yurttaş, 2010). Ebeveynleri tarafından reddedilen ve baskıcı aile ortamı, sosyal ilişki geliştirmede başarısız olmaya yol açabilmektedir (Yörükoğlu, 2019). Demokratik aile ortamında yetişen, anne babayla olumlu ilişkiler içinde olan ergenlerin akranlarıla olumlu ilişkiler kurdukları belirtilmektedir (Hortaçsu, 2003; Akt. Totan ve Yöndem, 2007; Kulaksızoğlu, 2004).

Ergenin meydana gelen olumsuz davranışlarının temelinde büyük ölçüde ergen- ebeveyn ilişkisi ve ebeveyn tutumlarının olması bu konuda çalışmaların yapılmasının önemini ortaya koymaktadır (Musaağaoğlu ve Güre, 2005; Acun Kapıkıran, 2011; Kocayörük, 2012). Anne baba davranışlarını bütün olarak yansıtan anne babalık biçimlerinin pek çok çalışmaya konu olduğu görülmektedir. Ancak anne babalık biçimleri yaklaşımında hangi davranışın ergen gelişimi üzerinde katkısı olduğu anlaşılamaması nedeniyle son yıllardaki çalışmalarda anne babalık biçimlerini oluşturan unsurların ayrı ayrı ele alındığı anne babalık davranışları yaklaşımının öne çıktığı görülmektedir. Anne babalık biçimlerinin temel boyutlarını; Duyarlı olma/özen gösterme, davranışsal denetim, psikolojik kontrol (Sevim, 2014) ve daha sonradan eklenen özerklik desteği oluşturmaktadır (Silk, Morris, Kanaya, Steinberg, 2003).

Ergen çevresiyle etkileşim halindeyken, yetişkinliğe geçişte kazanılması önemli bir beceri özerkliktir (Tung ve Dhillon, 2006; Steinberg, 2007; Lynch, 2013). Ergenin giderek artan bağımsız bir tutum içerisinde uygun kararlar 
verebilme becerisini geliştirmesi önemlidir (Calp, Karaman ve Çavuşoğlu, 2018). Özerklik, yaşam boyunca ergenin yaşantıları, aileleri, arkadaşları ve diğer bireylerle ilişkileri yoluyla şekillenir. Ergenlerin ruh sağlı̆̆ını önemli düzeyde etkilediği düşünülen özerklik; çeşitli şekillerde kişilerarası ilişkileri, kimliği, psikolojik uyumu etkilemekte (Morsünbül, 2012), suça yönelme, madde kullanımı gibi riskli davranışlardan korumada ve mesleki yaşantıda üst hedeflere ulaşmada etkili olması açısından önemli olduğu belirtilmektedir (Özdemir ve Çok, 2011). Bireyin yeteneklerini üretken bir şekilde ortaya koyarak hakkını savunabilmesi ve toplumda üzerine düşen görevleri yerine getirmesinde özerklik oldukça önemlidir.

Ergenlik döneminde fiziksel, bilişsel, sosyal değişim ile oluşan yeni hak ve sorumluluklar özerklik gelişimini hızlanmaktadır (Özdemir ve Çok, 2011). Ergenlik dönemine odaklanan Noom (1999) bütünleyici bir yaklaşımla özerklik gelişim modeli oluşturmuştur. Bu gelişim modeline dayalı olarak özerklik genel anlamda çalışmalarda tutumsal, duygusal ve işlevsel özerklik şeklinde ele alınmaktadır (Noom, Dekovic ve Meeus, 2001).

Anne baba davranışları, akran ilişkileri gibi çevresel faktörler ile gelişim karşılıklı olarak birbirinden etkilenmektedir. Ergenlik döneminin iki önemli çevresel faktörü olan anne baba davranışları ve akran ilişkileri ile gelişimsel bir gereksinim olan özerklik karşılıklı olarak birbirini etkilemektedir. Alanyazın incelendiğinde yapılan araştırmalar, ebeveynlerin çocuk yetiştirme tutumlarının ergenlik dönemindeki özerklik gelişimi ile yakından ilişkili olduğunu göstermektedir (Peterson, Bush ve Supple, 1999; Musaağaoğlu, 2004; Soenens ve Vansteenkiste, 2005; Yılmazer, 2007; Golonka, 2013). McElhaney ve Allen (2001) özerkliği desteklenen ergenlerin, aile ve akranlarıyla ilişkilerinin, sosyal yaşam becerilerinin daha iyi düzeyde olduğunu ifade etmektedir.

Ergenlerin algıladığı anne baba davranışları ve özerklik ilişkisine bakıldığında; anne ve babayla olan olumlu, destekleyici ilişkiler, kişilik ve benlik oluşumu, bağımsızlık kazanma ve toplumsallaşma üzerinde oldukça önemlidir (Yörükoğlu, 2019). Çocukla iletişim, yakınlık, ebeveynlerle çocuk arasında bağlılık ve çocuğun bireyselliği ve kendi ayaklarının üzerinde durmasının desteklendiği demokratik aile yapısı pek çok araştırmaya göre özerkliğin gelişimine olumlu katkı sağladığ (Peterson, Bush ve Supple, 1999; Yılmazer, 2007; Koç, 2019), otoriter aile yaklaşımlarının ise çocuklarının özerkliğini kısıtlayıcı olduğunu göstermektedir (Smetana, 1995).Buna göre çocuk 
ve ebeveyn ilişkilerinde ilişkililik ve özerkliğin birlikte, psiko-sosyal gelişimde olumlu rolünün olacağı belirtilmektedir (Grotevant ve Cooper, 1986; Frank, Avery ve Laman, 1988; Smollar ve Youniss, 1989; Allen, Hauser, Bell ve O'Connor, 1994; Y1lmaz, 2001).

Özerklik, ana babalık biçimleri yanında sosyal yapılara uyum ve bağımsız olma becerisi ile ilişkilidir. Bireyin bağımsız hareket edebilmesi kadar sosyal çevre ile uyumunu da işaret özerklik, sosyal çevreden bağımsız olarak düşünülemez. Özerklik, kendini kabul etmek ve diğerleriyle ilişki içinde olarak kendini onlara da kabul ettirmek süreçlerinin hassas dinamikleri üzerine inşa edilmiş bir yapıdır (Karasu, 2013). Bu bağlamda ergenlik döneminin önemli bir yönü olan arkadaş ilişkilerinin dinamikleri ile özerklik gelişimi yakından ilişkilidir. Akran gruplarının, ergenin bireyselleşmesine ve toplumda bağımsız bir birey olmasına birçok katkısı vardır (Kaner, 2000).

Yurtiçi alanyazında özerkliğin gelişimi ile ana-baba tutum ve davranışları arasındaki ilişkinin araştırıldığı çalışmalar 2000'li yıllardan sonra başladığı ve çok sayıda çalışmanın olmadığı dikkat çekmektedir (Aydın, 2000; Öngen, 2004; Musaağaoğlu ve Güre, 2005; Yılmazer, 2007; Çelik, 2015; Kayar, 2016; Koç, 2019). Ergen gelişimi çalışmaları açısından önemli olan anne baba davranışları bu çalışmanın önemli bir değişkeni olmakla birlikte, alanyazında anne ve babadan algılanan davranış tarzlarının ayrı ayrı incelendiği çalışma oldukça sınırlı kalmıştır. Ergenin her iki ebeveyninden algıladığ 1 davranış tarzlarının farklılaşabileceği ve iki ebeveynin ergen üzerinde farklı etkileri olabileceği düşünülmektedir. Bu farkın belirlenmesi ergenlik dönemi çalışmaları ve ebeveynlere yönelik olarak, iki ebeveyn için de ayrı ayrı psikoeğitim çalışmalarının yeniden şekillenmesinde ve daha işlevsel olmasında etkili olacağı düşünülmektedir.

Bu çalışmada ergenlerde ana babalık davranışları ile akran ilişkileri arasında özerkliğin aracı etkisinin ortaya konması amaçlanmıştır. Anne baba ve akran ilişkilerinin ergen davranışları üzerinde önemli unsurlar olması nedeniyle ergenlerin anne babaları ve akranlarıyla olan ilişkilerini inceleyen çalışmalar önem taşımaktadır. Ergenlik döneminde ön plana çıkan özerklik ve akran ilişkilerinin birlikte ele alındığı çok az sayıda çalışma olmakla birlikte bu çalışmalarda akran ilişkilerinin sosyal destek bağlamı içerisinde ele alındığı görülmektedir (Erçevik, 2014; Güney, 2017). Ayrıca özerklik, akran ilişkileri ve ergenin davranışları üzerinde önemli belirleyici olan ana babalık davranışlarının bir arada incelendiği bir araştırmaya rastlanmamıştır. 
$\mathrm{Bu}$ araştırmanın değişkenleri olan anne baba davranışları, akran ilişkileri ve özerklik ergenlik dönemin üç önemli bileşenini oluşturmaktadır. Alanyazın incelendiğinde bu yapıların birbiriyle bağlarının olduğu görülmektedir. Ergenlik döneminde birçok değişimin yanında artan bağımsızlık, anne baba davranışlarında değişim ve akran ilişkilerine yönelim gözlenmektedir. Ergenlik dönemi çalş̧malarında önemli yer tutan ve ergenlik döneminin gelişim görevlerinden de olan akranlarla ilişkilerin, sosyal gelişim, bireyselleşme, kimlik oluşumu ve toplum içerisinde bağımsız olarak yer edinme üzerindeki önemli etkileri düşünüldüğünde; akran ilişkilerini etkileyen yapıların incelenmesinin önemi ortaya çıkmaktadır. Bağımsızlaşma ihtiyacı ile ergen anne babasından akranlarına yaklaşmaktadır. Anne baba davranışlarının akran ilişkileri üzerinde etkisi olduğu, bununla birlikte ergenlikte olgunlaşan önemli bir beceri olan özerkliğin bahsedilen anne baba ve akran ilişkisi üzerinde önemli bir rolünün olduğu düşünülmektedir.

\section{Yöntem}

Araştırma değişkenleri arasındaki ilişkilerin yapısal eşitlik modeli çerçevesinde incelendiği bu araştırma betimsel nitelikli bir çalışmadır. Bu araştırmada ergenlerde algılanan anne baba davranışları ile akran ilişkileri arasında özerkliğin aracı rolünü incelemek için ilişkisel tarama modeli kullanılmıştır. Anne baba davranışları için model ayrı ayrı test edilmiştir.

Araştırma, 2018-2019 eğitim öğretim yılında Gaziantep ilinin Şehitkamil ilçesindeki devlet okullarına devam etmekte olan fen, anadolu ve meslek liselerinde öğrenim gören öğrencilerle yapılmış, 974 lise öğrencisinden veri toplanmıştır. Çalışma grubu belirlenirken her okul türünün evreni temsil etmesi açısından önce tabakalı sonra da ilgili okullardaki öğrencilere ulaşılabilirlik kolay olması açısından seçkisiz örnekleme kullanılmıştır. Araştırmada uç değerleri belirlemek için 'Mahalonobis Uzaklığı' yöntemi kullanılmış olup değişkenlerin z puanları incelenmiş ve -4 ile +4 arasında yer almayan bir değer bulunmamıştır. Ayrıca araştırma katılımcısı ergenlerden ölçek maddelerini \% $\% 5^{\prime}$ ten fazla boş bırakan 11 öğrencinin verileri analizden çıkarıldığında 519' u kadın (\%53,9), 444' ü erkek (\%46,1) olmak üzere toplam 963 lise öğrencisi araştırmanın çalışma grubunu oluşturmuştur. Çalışma grubunun 38' i $(\% 3,9) 14$ yaşında, 199' u $(\% 20,7) 15$ yaşında, 359' u $(37,3)$ 16 yaşında, 295' i $(\% 30,6) 17$ yaşında, 72' si $(\% 7,5) 18$ ve üstü yaşındadır. 
Ayrıca araştırmaya katılan ergenlerin 257' si $(\% 26,7)$ fen lisesinde, 331' i $(\% 34,4)$ anadolu lisesinde ve $375^{\prime}$ i $(\% 38,9)$ meslek lisesinde öğrenim görmektedir. Bununla birlikte ergenlerin 198' i $(\% 20,6)$ 9. sinif, 342' si $(\% 35,5)$ 10. sınıf, $318^{\prime}$ i $(\% 33) 11$. sinıf ve $105^{\prime}$ i $(\% 10,9) 12$. sınıf düzeyinde öğrenim görmektedir.

$\mathrm{Bu}$ araştırmada ergenlerin; akran ilişkileri düzeyini belirlemek için Kaner (2000) tarafından geliştirilen 'Akran İlişkileri Ölçeği' (AİÖ), anne baba davranışların belirlemek için Sevim (2014) tarafından Türkçe' ye uyarlanan ‘Leuven Algılanan Ana Babalık/Ergen Sürümü Ölçeği' (LAAÖ/e) ve özerklik düzeyini ölçmek için Musaağaoğlu (2004) tarafından Türkçe' ye uyarlaması yapılan ‘Ergen Özerklik Ölçeği' (EÖÖ), kullanılmıştır. Ayrıca araştırmaya katılan ergenlerin demografik bilgileri için araştırmacının hazırlamış olduğu kişisel bilgi formu kullanılmıştır.

Araştırma verilerinin toplanması amacıyla gerekli izinlerin alınmasının ardından okul psikolojik danışmanı/rehber öğretmenlerin de desteğiyle ölçekler araştırmacı tarafından ders saatinde öğrencilere uygulanmıştır. Katılımda gönüllüğün önemli olduğu da belirtilerek ölçekler araştırmaya katılmaya gönüllü olan öğrencilere dağıtılmış olup uygulama 20-25 dk arasinda sürmüştür.

Araştırma kapsamında toplanan verilerin analizi SPSS 21 paket programi ve AMOS (Analysis of Moment Structures) 22.0 programı kullanilarak gerçekleştirilmiştir. Ergenlerde algılanan anne baba davranışlarıyla akran ilişkileri arasında özerkliğin aracı rolünün olup olmadığı anne ve baba için ayrı ayrı modellerde yapısal eşitlik modeliyle (YEM) analiz edilmiştir.

Bu çalışmada da YEM, Anderson ve Gerbing (1988) ile Kline (2015)' in önerdiği şekilde ölçme modeli ve yapısal model olmak üzere iki aşamada gerçekleştirilmiştir. Ölçme modelinde gözlenen değişkenlerle gizil değişkenler arasındaki bağlantı yön belirtmeksizin birlikte ele alınmakta ve modelin doğrulanıp doğrulanmadığı incelenmektedir. Ölçme modelinin ardından hipotetik olarak kurulan yapısal modelin incelenmesine geçilmektedir. Yapısal modelse gizil değişkenler arasındaki ilişkileri özetleyen yapısal eşitlikleri kapsamaktadır (Çelik ve Yılmaz, 2016). Ayrıca bu çalışmada ergen özerkliği (EÖÖ Par 1, EÖÖ Par2) ve arkadaş ilişkileri (AİÖ Par 1, AïÖ Par 2) gizil değişkenlerini oluşturmak için, incelenen modellerde uyum indekslerini iyileştirmek amaciyla Bandalos (2002) tarafından önerilen parselleme yöntemi kullanılmıştır. Bu çalışmada, çok değişkenli normalliğe sahip mo- 
dellerin standardizasyonunda sıklıkla kullanılan bir yöntem olan En Çok Olabilirlik (maximum likelihood) yöntemi kullanılmıştır. Ayrıca bununla birlikte modelin veriye olan uygunluğunun incelenmesinde bir takım uyum ölçütlerinden yararlanılmıştır. Bunlar; GFI (goodness of fit index), AGFI (adjusted goodness of fit index), CFI (comparative fit index), NFI (Normed Fit İndex), TLI (Tucker Lewis Index), RMSEA (root mean square residual), SRMR (standardized root mean square residual) ve $\mathrm{x}^{2}$ (Ki-Kare) değerinin sd (serbestlik derecesine) oranıdır. Şimşek (2007) ve Kline (2015)' e göre $x^{2}$ / sd değerinin 2 veya daha altında olması, GFI, AGFI,CFI, NFI ve TLI değerlerinin $.95^{\prime}$ ten büyük olması ayrıca RMSEA ve SRMR değerlerinin de $.05^{\prime}$ in altında olması iyi uyum iyiliği değerlerini, $x^{2} /$ sd değerinin 5 veya daha altında olması, GFI, AGFI,CFI, NFI ve TLI değerlerinin $.90^{\prime}$ dan büyük olması ayrıca RMSEA ve SRMR değerlerinin de $.08^{\prime}$ in altında olması kabul edilebilir bir uyum iyiliği değerlerinin göstergesidir.

Anne baba davranışlarıyla akran ilişkileri arasında özerkliğin aracı rolünün olup olmadığını belirlemek için Baron ve Kenny (1986)' nin önerileri dikkate alınmıştır. Baron ve Kenny (1986)' e göre; a)bağımsız değişkenlerle bağımlı değişken anlamlı ilişkiye sahiptir, b)bağımsız değişkenle aracı değişken anlamlı ilişkiye sahiptir, c)aracı değişkenle bağımlı değişken anlamlı ilişkiye sahiptir, d)aracı değişkenin modele dahil olduğunda bağımsız değişkenin bağımlı değişken üzerindeki ilişkisi azalmaktadır.

Ayrıca bu çalışmada aracılığın anlamlı olup olmadığına ilişkin ek kanıt elde etmek için Bootstrapping ve Sobel testi kullanılmıştır.

\section{Bulgular}

Bu bölümde araştırma problemi olan 'Ergenlerde algılanan anne baba davranışları ile akran ilişkileri arasında özerkliğin aracı rolü var mıdır ?' sorusuna yanıt verecek nitelikteki bulgulara yer verilmiştir.

\section{Algılanan Anne Baba Davranışları, Akran İlişkileri ve Özerklik Arasındaki İlişkiler}

Algılanan anne baba davranışları, akran ilişkileri ve özerklik arasındaki ilişki Pearson Momentlar Çarpımı Korelasyonu ile hesaplanmış ve sonuçlara Tablo 1.' de yer verilmiştir. 
Tablo 1. Algılanan anne baba davranışları, akran ilişkileri ve özerklik arasında Pearson Momentler Çarpımı Korelasyon Testi sonuçlan

\begin{tabular}{|c|c|c|c|c|c|c|c|c|c|c|c|c|}
\hline & 1 & 2 & 3 & 4 & 5 & 6 & 7 & 8 & 9 & 10 & 11 & 12 \\
\hline 1. EOOPar1 & - & & & & & & & & & & & \\
\hline 2. EOOPar2 & $.72 *$ & - & & & & & & & & & & \\
\hline 3. AIOOPar1 & $.32 *$ & $.30^{*}$ & - & & & & & & & & & \\
\hline 4. AİOPar2 & $.31^{*}$ & $.28^{* *}$ & $.76^{* *}$ & - & & & & & & & & \\
\hline 5. Anneduy & $.31^{* *}$ & $.27^{\prime \prime \prime}$ & $.28^{* *}$ & $.24^{*}$ & - & & & & & & & \\
\hline 6. Annedavden & $.22^{* *}$ & $.20^{*}$ & $.26^{* *}$ & $.24^{* *}$ & $.43^{* *}$ & - & & & & & & \\
\hline 7. Annepsikon & $-.12^{* w}$ & $-.13^{* \prime \prime}$ & $-.12^{* 4}$ & $-.13^{* * 4}$ & $-.19^{* *}$ & $-.08^{*}$ & - & & & & & \\
\hline 8. Anneozdes & $.33^{*}$ & $.31^{*}$ & $.27^{\prime \prime \prime}$ & $.26^{*}$ & $.63^{* *}$ & $.56^{*}$ & $-.11^{* *}$ & - & & & & \\
\hline 9. Babaduy & $.27^{\prime \prime \prime}$ & $.24^{*}$ & $.23^{*}$ & $.18^{* *}$ & $.41^{*}$ & $.16^{* \prime \prime}$ & $-.14^{*+*}$ & $.31^{* *}$ & - & & & \\
\hline 10 Babadavden & $.31^{*}$ & $.26^{* *}$ & $.31^{* *}$ & $.31^{*}$ & $.29^{* *}$ & $.57^{*}$ & $-.15^{*+*}$ & $.38^{* *}$ & $.38^{* *}$ & - & & \\
\hline 11. Babaozdes & $.33^{* *}$ & $.30^{*}$ & $.23^{* *}$ & $.19^{* *}$ & $.36^{* *}$ & $.29^{* *}$ & $-.09^{*+*}$ & $.49^{* *}$ & $.63^{* *}$ & $.53^{* *}$ & - & \\
\hline 12. Babapsikon & $.15^{*}$ & $.12^{* *}$ & $.15^{* *}$ & $.15^{* *}$ & $.08^{* *}$ & $.06^{*}$ & $-.21^{* *}$ & .04 & $.07^{+}$ & $.12^{* *}$ & .05 & - \\
\hline
\end{tabular}

Not. ${ }^{*} \mathrm{p}<.05 ;{ }^{* *} \mathrm{p}<$.01; EÖÖ Par ergen özerklik ölçeği parselleri; AİÖ Par akran ilişkileri ölçeği parselleri; Anneduy anne duyarlık alt boyutu; Annedavden anne davranışsal denetim alt boyutu; Annepsikon anne psikolojik kontrol alt boyutu; Anneozdes anne özerklik desteği alt boyutu; Babaduy baba duyarlık alt boyutu; Babadavden baba davranıssal denetim alt boyutu; Babaozdes baba özerklik desteği alt boyutu; Babapsikon baba psikolojik kontrol alt boyutu

Tablo 1. incelendiğinde; EÖÖ parselleri, AİO parselleri ve algılanan anne baba davranışlarının birbiriyle pozitif ne negatif yönde anlamlı ilişkileri olduğu görülmektedir. Ayrıca araştırma verilerine ait çarpıklık ve basıklık değerleri incelendiğinde, normallik değerlerinin -1.5 ile +1.5 arasında yer aldığı görülmektedir. Bu durumda Bachman' in (2004) ve George ve Mallery' nin (2003) çarpıklık ve basıklık değerlerinin -2 ile +2 arasında değer alması gerekliliği vurgusunu sağlamasından dolayı normallik varsayımını karşıladığ1 söylenebilir.

\section{Algılanan Anne Davranışlarn, Akran İlişkileri ve Özerkliğe İlişkin Ölçme Modeli}

Algılanan anne davranışlarıyla akran ilişkileri arasında özerkliğin aracılık rollerinin inceleneceği yapısal eşitlik modellemesinde ilk olarak ölçme modelinde üç adet gizil değişken (anne davranışları, akran ilişkileri, özerklik) ile bu gizil değişkenleri oluşturacak sekiz adet gözlenen değişken bulunmaktadır. Anne davranışları gizil değişkenini; duyarlık, davranışsal denetim, psikolojik kontrol ve özerklik desteği oluşturmaktadır. Akran ilişkileri gizil değişkenini iki parsel temsil etmektedir. Özerklik gizil değişkenini de 
benzer biçimde iki parsel temsil etmektedir. Şekil 1.' de oluşturulan ölçme modeline ait doğrulayıc faktör analizi sonuçları yer almaktadır.

Ölçme modeli sonuçlarında ilk olarak standardize edilmiş regresyon katsayılarının anlamlılığı incelenmiştir. Şekil 1.' deki oluşturulan ölçme modelinde standardize edilmiş regresyon katsayılarının tümünün anlamlı olduğu görülmektedir $(\mathrm{p}<.01)$. Aynı zamanda gizil değişkenler arasındaki ilişkilerinde anlamlı olduğu görülmektedir. Ölçme modelinin doğrulanıp doğrulanmadığına ilişkin incelenen uyum iyiliği indeksleri şu şekilde bulunmuştur; $x^{2} / d f=2.57, G F I=.98, A G F I=.97, C F I=.99, N F I=.98, T L I=.98, R M S E A=.040$, $S R M R=.029$. Anne davranışlarıyla akran ilişkileri ve özerkliğe ilişkin ölçme modelinin kabul edilebilir uyum iyiliği indekslerine sahip olduğu anlaşımaktadır.

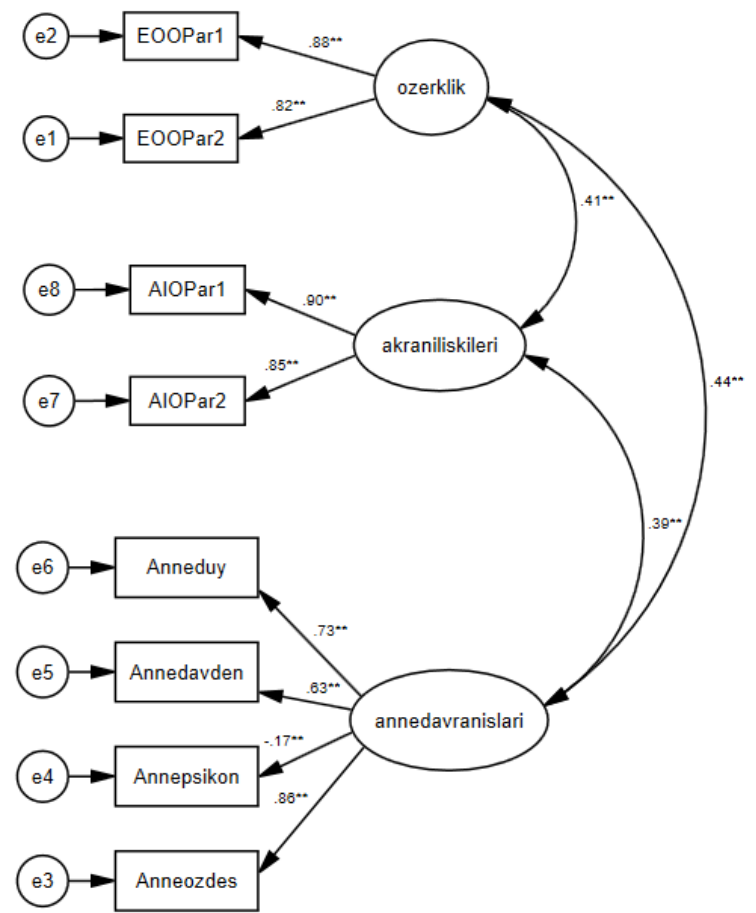

Şekil 1. Ölçme Modeli, EÖÖ Par ergen özerklik ölçeği parselleri; AİÖ Par akran ilişkileri ölçeği parselleri; Anneduy anne duyarlık alt boyutu; Annedavden anne davranışsal denetim alt boyutu; Annepsikon anne psikolojik kontrol alt boyutu; Anneozdes anne özerklik 


\section{Algılanan Anne Davranışları İle Akran İlişkileri Arasında Özerkliğin Aracı Rolüne İlişkin Yaptsal Model}

Ölçme modelinin doğrulanmasının ardından algılanan anne davranışlarıyla akran ilişkileri arasında özerkliğin aracı rolünün incelenmesi için yapısal model sınanmıştır. Yapısal modelin sınanmasında Baron ve Kenny' nin (1986) önerileri dikkate alınmıştır. Bunun için öncelikle aracı değişken modele dahil edilmeden bağımsız değişkenin (anne davranışları) bağımlı değişkeni (akran ilişkileri) doğrudan yordayıp yordamadığı incelenmiştir. Ardından aracı değişkenler modele dahil edilmiş ve bu kapsamda en iyi modeli belirleyebilmek için sırasıyla tam aracı ve kısmi aracı modeller incelenmiş olup Kline (2015)' in belirttiği şekilde daha düşük AIC (Akaike's Information Criterion) ve ECVI (Expected Cross Validation Index) değerlerini sunan aracılık modelinin en uygun model olduğuna karar verilmiştir. Ayrıca oluşturulan modeldeki aracılık etkisinin anlamlılığını test etmek amacıyla Sobel Testi yapılmıştır.

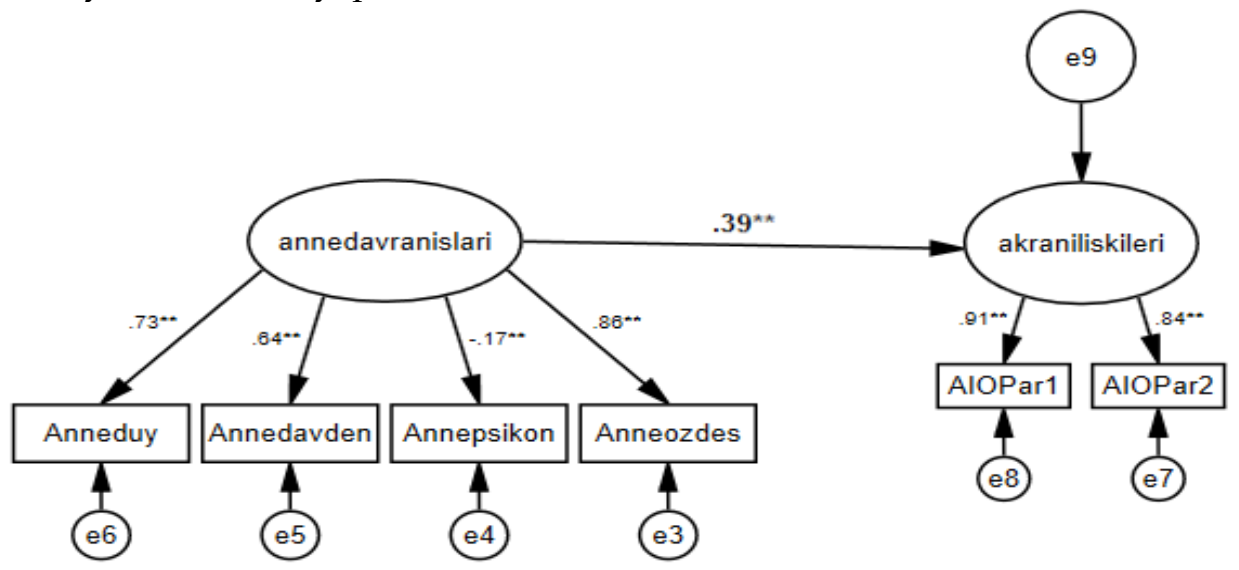

Şekil 2. Algılanan Anne Davranışlarınn Akran Iliş̧kilerini Yordamasına İlişkin Standardize Edilmiş Regresyon Katsayıları. AïÖ Par akran ilişsileri ölçeği parselleri; Anneduy anne duyarlık alt boyutu; Annedavden anne davransssal denetim alt boyutu; Annepsikon an anne psikolojik kontrol alt boyutu; Anneozdes anne özerklik desteği alt boyutu

Kurulan model sonucunda oluşan uyum iyiliği indeksleri şu şekilde bulunmuştur; $x^{2} / d f=4.27, G F I=.98, A G F I=.96, C F I=.98, N F I=.98, T L I=.97$, $R M S E A=.058, S R M R=.031$. Algılanan anne davranışlarının akran ilişkilerini 
yordamasına ait modelin uyum iyiliği indekslerinin kabul edilebilir değerler arasında olduğu görülmektedir.

Yapılan analizler sonucunda modele ait standardize edilmemiş regresyon katsayısının (b) .49, standart hatalar (Std.Hata) katsayısının .05, kritik değerler (K.D.) katsayısının 9.94 olduğu bulunmuştur. Elde edilen bu veriler ve Şekil 2.' de sunulan algılanan anne davranışlarının akran ilişkilerini yordamasına ilişkin beta $(\beta)$ katsayısının .39 olduğu ve bu değerinde anlamlı olduğu belirlenmiştir $(\mathrm{p}<.01)$. Bu işlemin ardından aracı modelin incelenmesine geçilmiştir. İlk önce tam aracı model incelenmiştir. Tam aracı modelde bağımsız değişkenden bağımlı değişkene giden doğrudan yol bulunmamakta, yordama tamamen aracı değişken üzerinden gerçekleşmektedir. Algılanan anne davranışlarıyla akran ilişkileri arasında özerkliğin tam aracı rolünü inceleyen modele ilişkin sonuçlara Şekil 3.' te yer verilmiştir.

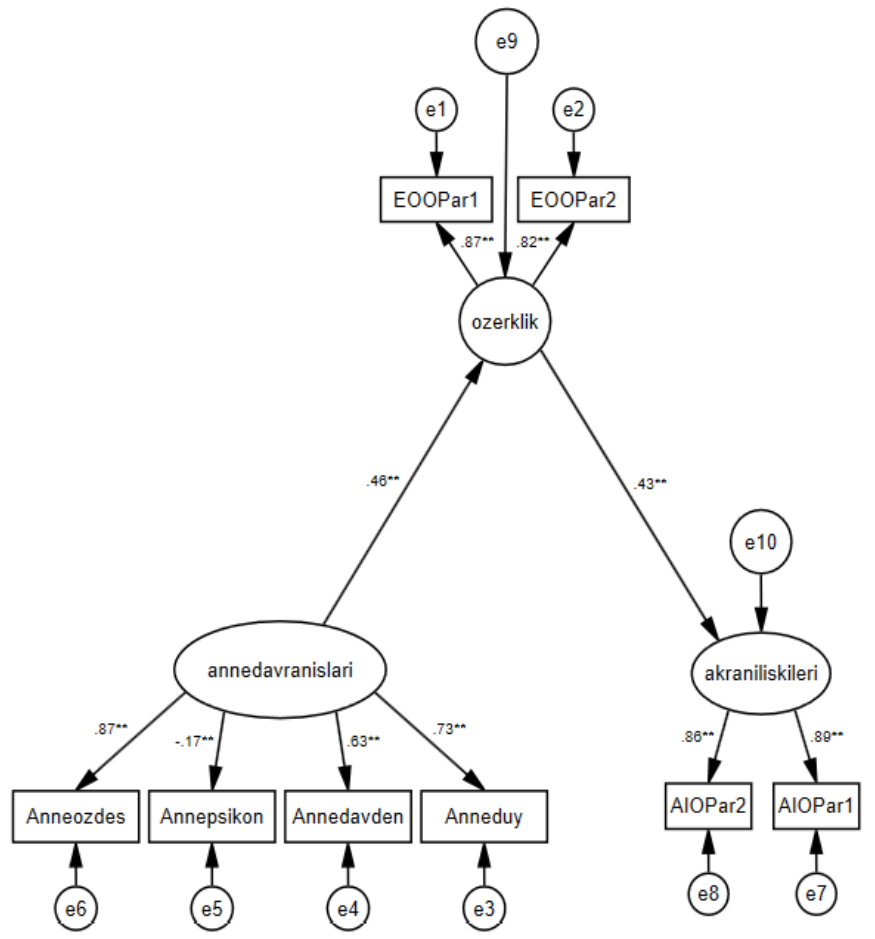

Şekil 3. Algılanan Anne Davranışlarıyla Akran İlişkileri Arasında Özerkliğin Tam Aracı Rolüne İlişkin Standardize Edilmiş Regresyon Katsayzları. EÖÖ Par ergen özerklik ölçeği parselleri; AİÖ Par akran ilişskileri ölçeği parselleri; Anneozdes anne özerklik 
desteği alt boyutu; Annepsikon anne psikolojik kontrol alt boyutu; Annedavden anne davranişsal denetim alt boyutu; Anneduy anne duyarlik alt boyutu

Şekil 3.' te sunulan algılanan anne davranışlarıyla akran ilişkileri arasında özerkliğin tam aracı rolünün incelendiği yapısal eşitlik modelinde tüm yol katsayılarının anlamlı olduğu görülmektedir. Dolaylı etki incelendiğinde anne davranışları akran ilişkilerini özerklik aracılığıyla etkilediği, standardize edilmiş dolaylı etki katsayısının .20 olduğu bulunmuştur. Ayrıca anne davranıslarının akran ilişkilerini yordamasına ilişkin beta $(\beta)$ katsayısının .46, özerkliğin akran ilişkilerini yordamasına ilişkin beta $(\beta)$ katsayısının .43 olduğu ve bu değerlerinde anlamlı olduğu belirlenmiştir $(p<.01)$.

Algılanan anne davranışlarıyla akran ilişkileri arasında özerkliğin tam aracı rolüne ait yapısal modelin uyum iyiliği indeksleri şu şekilde bulunmuştur; $x^{2} / d f=4.62$, GFI= .97, AGFI= .95, CFI=.97, NFI= .97, TLI= .96, RMSEA= $.061, S R M R=.064, \mathrm{AIC}=119.303, \mathrm{ECVI}=.124$. Elde edilen değerlerin kabul edilebilir değerler arasında olduğu görülmektedir.

Tam aracılık modelinin ardından algılanan anne davranışlarıyla akran ilişkileri arasında özerkliğin kısmi aracılığı test edilmiştir. Anne davranışlarıyla akran ilişkileri arasında özerkliğin kısmi aracı rolünü inceleyen modele ilişkin sonuçlara Şekil 4.' te yer verilmiştir. 


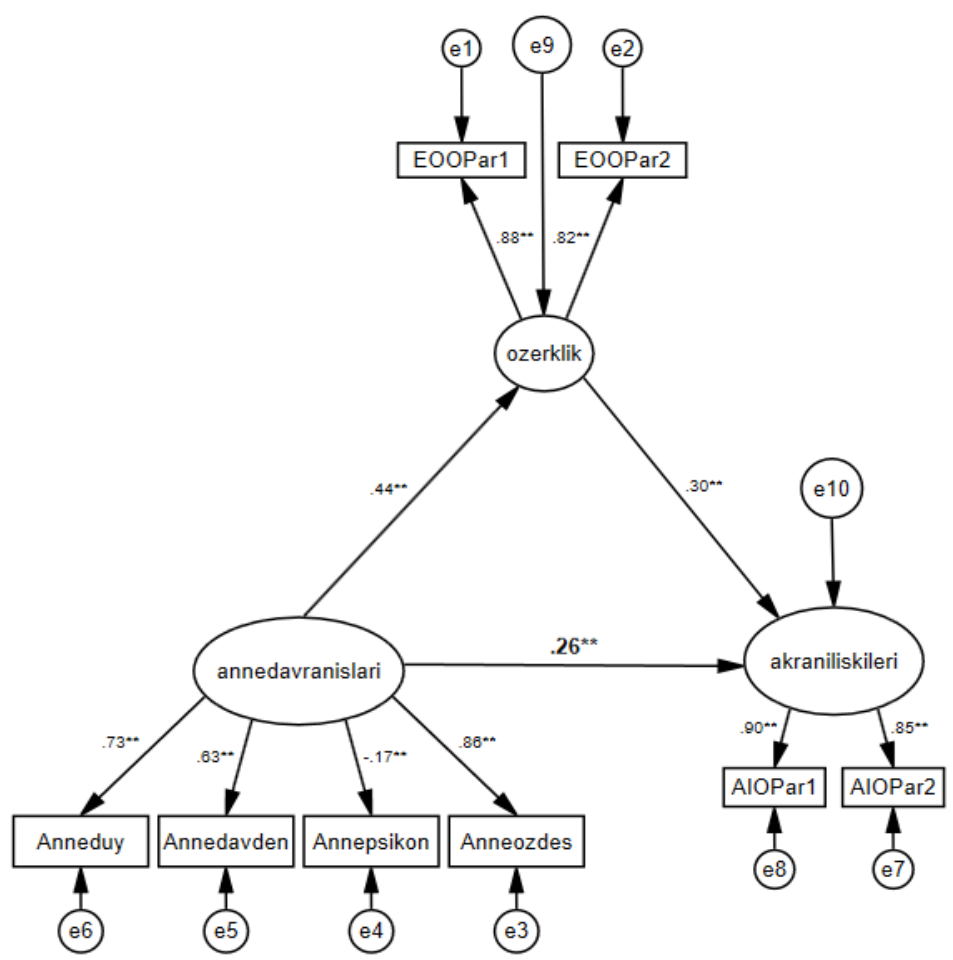

Şekil 4. Algılanan Anne Davranışlarıyla Akran İlişkileri Arasında Özerkliğin Kısmi Aracı Rolïne İlişkin Standardize Edilmiş Regresyon Katsayılan EÖÖ Par ergen özerklik ölçeği parselleri; AïÖ Par akran ilişkileri ölçeği parselleri; Anneduy anne duyarlık alt boyutu; Annedavden anne davranışsal denetim alt boyutu; Annepsikon anne psikolojik kontrol alt boyutu; Anneozdes anne özerklik desteği alt boyutu.

Şekil 4.' te sunulan algılanan anne davranışlarıyla akran ilişkileri arasında özerkliğin kısmi aracı rolünün incelendiği yapısal eşitlik modelinde tüm yol katsayılarının anlamlı olduğu görülmektedir. Dolaylı etki incelendiğinde anne davranışları akran ilişkilerini özerklik aracılığıyla etkilediği, standardize edilmiş dolaylı etki katsayısının .13 olduğu bulunmuştur. Ayrıca anne davranışlarının özerkliği yordamasına ilişkin beta $(\beta)$ katsayısının .44, özerkliğin akran ilişkilerini yordamasına ilişkin beta $(\beta)$ katsayısının .30 , anne davranışlarının akran ilişkilerini yordamasına ilişkin beta $(\beta)$ katsayısinın .26 olduğu ve bu değerlerinde anlamlı olduğu belirlenmiştir $(p<.01)$. 
Algılanan anne davranışlarıyla akran ilişkileri arasında özerkliğin kısmi aracı rolüne ait ölçme modelinin uyum iyiliği indeksleri şu şekilde bulunmuştur; $x^{2} / d f=2.57, G F I=.98, A G F I=.97, C F I=.99, N F I=.98, T L I=.98, R M S E A=$ $.040, S R M R=.029, \mathrm{AIC}=81.808, \mathrm{ECVI}=.085$. Elde edilen değerlerin kabul edilebilir değerler arasında olduğu görülmektedir.

Test edilen aracilik modelleri incelendiğinde ve Kline (2015)' in önerileri göz önünde bulundurulduğunda kısmi aracı modelin AIC (81.808), ECVI (.085) değerlerinin tam aracı modele ait AIC (119.303), ECVI (.124) değerlerinden daha düşük olduğundan kısmi aracı modelin tercih edilmesine karar verilmiştir. Bunun yanında Baron ve Kenny' nin önerileri dikkate alındığında aracı değişkenin modele dahil edildiğinde anne davranışlarından akran ilişkilerine giden yolun .39' dan .26' ya düştüğü ve bu yolun halen anlamlı olması nedeniyle de kısmi aracı modelin bu araştırma kapsamında tercih edilmesi gerektiği anlaşılmıştır. Ayrıca aracılık rolünün anlamlılığını test etmek için yapılan Sobel testi sonucunda Sobel testi Z değerinin (6.13) 1.96' dan büyük çıkması özerkliğin anne davranışlarıyla akran ilişkileri arasında kısmi aracı role sahip olduğunu göstermektedir.

\section{Bootstrapping İşlemi}

Kısmi aracı modele ait doğrudan ya da dolaylı anlamlı olup olmadığına yönelik ek kanıt sağlamak amaciyla 10.000 yeniden örnekleme yoluyla gerçekleştirilen bootstrapping işlemi sonucunda bootstrapping katsayısı ve \% 95 güven aralıkları (G.A.) alt ve üst sınırları hesaplanmış olup, sonuçlara Tablo 2.'de yer verilmiştir.

Tablo 2. Kısmı aracı modele ait bootstrapping sonuçlan

\begin{tabular}{|c|c|c|c|}
\hline & & \%95 G.A. & \\
\hline Model Yolları & Katsay1 & Alt Sinir & Üst Sinır \\
\hline \multicolumn{4}{|l|}{ Doğrudan etki } \\
\hline Anne Davranışları-Özerklik & $.44^{*}$ & $.37^{*}$ & $.51^{*}$ \\
\hline Anne Davranışları-Akran İlişkileri & $.26^{*}$ & $.17^{*}$ & $.34^{*}$ \\
\hline Özerklik-Akran İlişkileri & $.30^{*}$ & $.21^{*}$ & $.37^{*}$ \\
\hline \multicolumn{4}{|l|}{ Dolaylı etki } \\
\hline Anne Davranışları-Özerklik-Akran İlişkileri & $.13^{*}$ & $.09^{*}$ & $.17^{*}$ \\
\hline
\end{tabular}

Bootstrapping işlemi sonucunda güven aralığı alt ve üst sınırı sıfır içermediğinde incelenen etkinin anlamlı olduğu belirtilmektedir (Preacher ve Hayes, 2008). Tablo 2. incelendiğinde, modeldeki etkilerin tümünün anlamlı 
olduğu sonucuna varılabilir. Hem doğrudan etkilerin hem de dolaylı etkilerin bootstrapping güven aralıkları alt ve üst sınırları sıfırı kapsamamaktadır. Bu nedenle bootstrapping analizinde de, ergenlerde algılanan anne davranışlarıyla akran ilişkileri arasında özerkliğin kısmi aracılık rolünün olduğu söylenebilir.

\section{Algılanan Baba Davranışları, Akran İlişkileri ve Özerkliğe İlişkin Ölçme Modeli}

Algılanan baba davranışlarıyla akran ilişkileri arasında özerkliğin aracılık rollerinin inceleneceği yapısal eşitlik modellemesinde ilk olarak ölçme modelinde üç adet gizil değişken (baba davranışları, akran ilişkileri, özerklik) ile bu gizil değişkenleri oluşturacak sekiz adet gözlenen değişken bulunmaktadır. Baba davranışları gizil değişkenini; duyarlık, davranışsal denetim, psikolojik kontrol ve özerklik desteği oluşturmaktadır. Akran ilişkileri gizil değişkenini iki parsel temsil etmektedir. Özerklik gizil değişkenini de benzer biçimde iki parsel temsil etmektedir. Şekil 5.' te oluşturulan ölçme modeline ait doğrulayıcı faktör analizi sonuçları yer almaktadır.

Şekil 5.' te de görüldüğü gibi alanyazına uygun şekilde (Gray ve Steinberg, 1999) baba duyarlık ve baba özerklik gözlenen değişkenlerinin hata kovaryansları birbirleriyle ilişkilendirilerek modelde iyileştirme yapılmıştır. Ölçme modeli sonuçlarında ilk olarak standardize edilmiş regresyon katsayılarının anlamlılığ 1 incelenmiştir. Şekil 5.' teki oluşturulan ölçme modelinde standardize edilmiş regresyon katsayılarının tümünün anlamlı olduğu görülmektedir $(\mathrm{p}<.01)$. Aynı zamanda gizil değişkenler arasındaki ilişkilerinde anlamlı olduğu görülmektedir. Ölçme modelinin doğrulanıp doğrulanmadığına ilişkin incelenen uyum iyiliği indeksleri şu şekilde bulunmuştur; $x^{2} / d f=3.39$, GFI=.98, AGFI= .96, CFI= .98, NFI= .98, TLI= .97, RMSEA= .050, $S R M R=.035$. Algılanan baba davranışlarıyla akran ilişkileri ve özerkliğe ilişkin ölçme modelinin kabul edilebilir uyum iyiliği indekslerine sahip olduğu anlaşılmaktadır. 


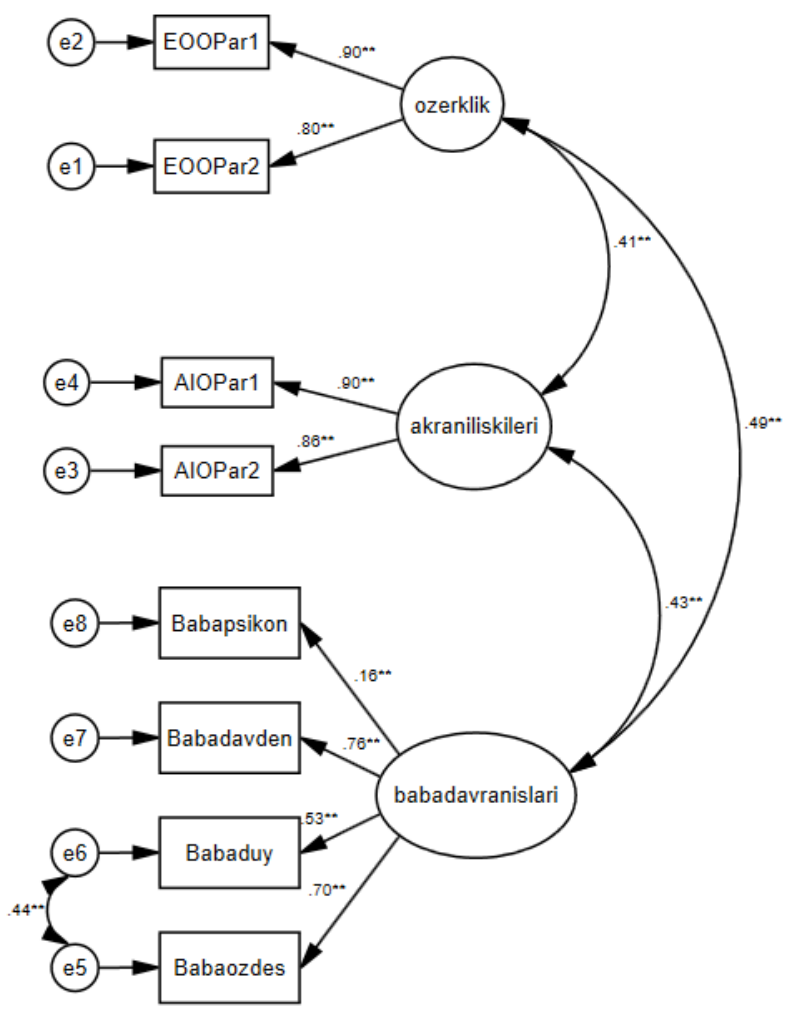

Şekil 5. Ölçme Modeli, EÖÖ Par ergen özerklik ölçeği parselleri; AİÖ Par akran ilişkileri ölçeği parselleri; Babapsikon baba psikolojik kontrol alt boyutu; Babadavden baba davranışsal denetim alt boyutu; Babaduy baba duyarlı alt boyutu; Babaozdes baba özerklik desteği alt boyutu

\section{Algılanan Baba Davranışlarıla Akran İlişkileri Arasında Özerkliğin Aracı} Rolüne İlişkin Yaptsal Model

Ölçme modelinin doğrulanmasının ardından algılanan baba davranışlarıyla akran ilişkileri arasında özerkliğin aracı rolünün incelenmesi için yapısal model sınanmıştır. Yapısal modelin sınanmasında Baron ve Kenny' nin (1986) önerileri dikkate alınmıştır. Bunun için öncelikle aracı değişken modele dahil edilmeden bağımsız değişkenin (baba davranışları) bağımlı değişkeni (akran ilişkileri) doğrudan yordayıp yordamadığı incelenmiştir. Ardından aracı değişkenler modele dahil edilmiş ve bu kapsamda en iyi modeli belirleyebilmek için sırasıyla tam aracı ve kısmi aracı modeller ince- 
lenmiş olup Kline (2015)' in belirttiği şekilde daha düşük AIC (Akaike's Information Criterion) ve ECVI (Expected Cross Validation Index) değerlerini sunan aracılık modelinin en uygun model olduğuna karar verilmiştir. Ayrıca oluşturulan modeldeki aracılık etkisinin anlamlılığını test etmek amacıyla Sobel Testi yapılmıştır.

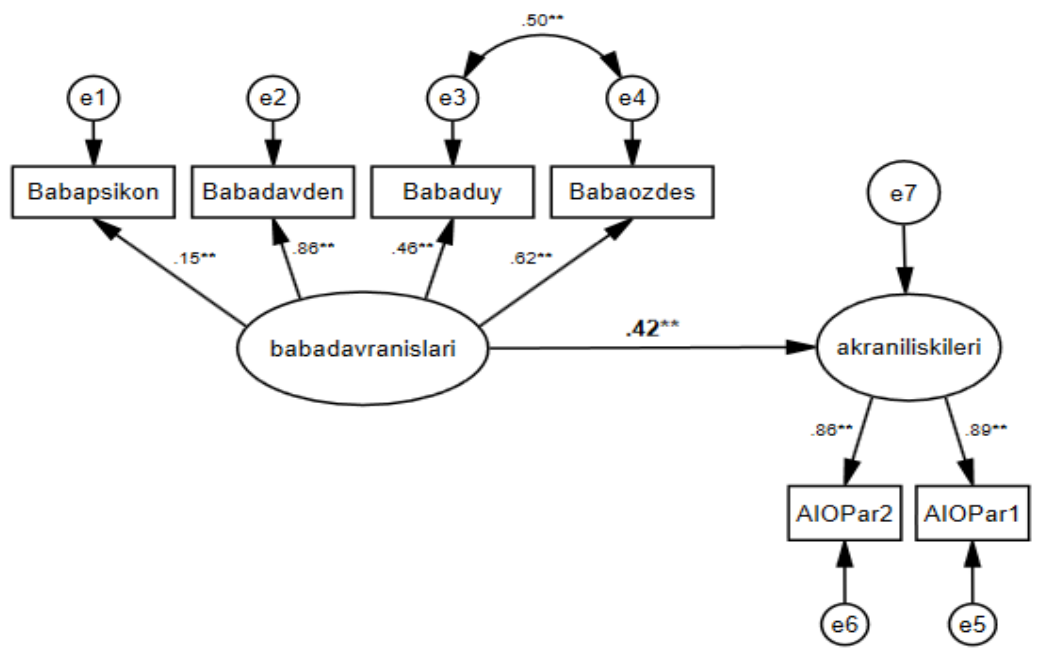

Şekil 6. Algılanan Baba Davranışlarnın Akran İlişkilerini Yordamasına İlişskin Standardize Edilmiş Regresyon Katsayıları. AïÖ Par akran ilişkileri ölçeği parselleri; Babapsikon baba psikolojik kontrol alt boyutu; Babadavden baba davranışsal denetim alt boyutu; Babaduy baba duyarlık alt boyutu; Babaozdes baba özerklik desteği alt boyutu

Kurulan model sonucunda oluşan uyum iyiliği indeksleri şu şekilde bulunmuştur; $x^{2} / d f=4.01, G F I=.99, A G F I=.97, C F I=.98, N F I=.98, T L I=.97$, $R M S E A=.056, S R M R=.034$. Algılanan baba davranışlarının akran ilişkilerini yordamasına ait modelin uyum iyiliği indekslerinin kabul edilebilir değerler arasında olduğu görülmektedir.

Yapılan analizler sonucunda modele ait standardize edilmemiş regresyon katsayısının (b) .70, standart hatalar (Std.Hata) katsayısının .08, kritik değerler (K.D.) katsayısının 8.49 olduğu bulunmuştur. Elde edilen bu veriler ve Şekil 6.' da sunulan baba davranışlarının akran ilişkilerini yordamasına ilişkin beta $(\beta)$ katsayısının .42 olduğu ve bu değerinde anlamlı olduğu belirlenmiştir $(p<.01)$. Bu işlemin ardından aracı modelin incelenmesine geçil- 
miştir. İlk önce tam aracı model incelenmiştir. Tam aracı modelde bağımsız değişkenden bağımlı değişkene giden doğrudan yol bulunmamakta, yordama tamamen aracı değişken üzerinden gerçekleşmektedir. Ergenlerde algılanan baba davranışlarıyla akran ilişkileri arasında özerkliğin tam aracı rolünü inceleyen modele ilişkin sonuçlara Şekil 7.' de yer verilmiştir.

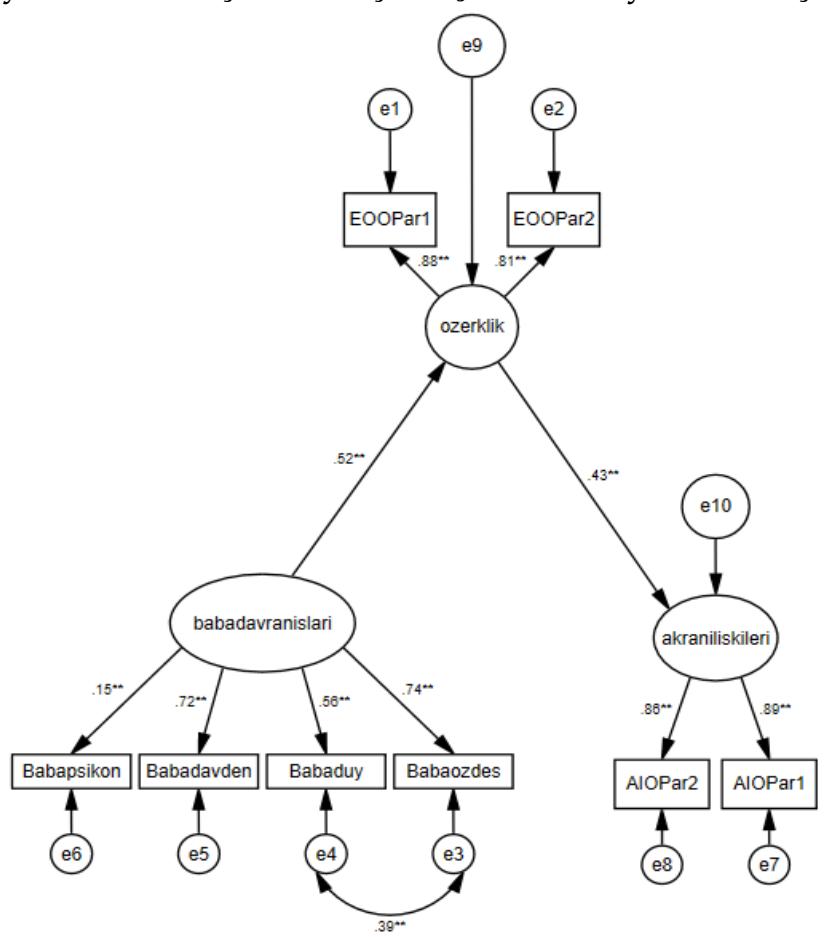

Şekil 7. Algılanan Baba Davranışlarnyla Akran İlişkileri Arasında Özerkliğin Tam Aracı Rolüne İlişkin Standardize Edilmiş Regresyon Katsayıları. EÖÖ Par ergen özerklik ölçeği parselleri; AİÖ Par akran ilişkileri ölçeği parselleri; Babapsikon baba psikolojik kontrol alt boyutu; Babadavden baba davranışsal denetim alt boyutu; Babaduy baba duyarlık alt boyutu; Babaozdes baba özerklik desteği alt boyutu

Şekil 7.' de sunulan algılanan baba davranışlarıyla akran ilişkileri arasında özerkliğin tam aracı rolünün incelendiği yapısal eşitlik modelinde tüm yol katsayılarının anlamlı olduğu görülmektedir. Dolaylı etki incelendiğinde baba davranışlarının akran ilişkilerini özerklik aracilığıyla etkilediği, standardize edilmiş dolaylı etki katsayısının .22 olduğu bulunmuştur. Ayrıca baba davranışlarının akran ilişkilerini yordamasına ilişkin beta $(\beta)$ katsa- 
yısının .52, özerkliğin akran ilişkilerini yordamasına ilişkin beta ( $\beta$ ) katsay1sının .43 olduğu ve bu değerlerinde anlamlı olduğu belirlenmiştir $(p<.01)$.

Algılanan baba davranışlarıyla akran ilişkileri arasında özerkliğin tam aracı rolüne ait yapısal modelin uyum iyiliği indekslerinden $x^{2} / d f$ değerinin kabul edilebilir değerlerin üzerinde çıktığından bu model kabul edilmemiştir. Buna göre; $x^{2} / d f=5.53, G F I=.97, \mathrm{~A} G F I=.95, C F I=.97, N F I=.96, T L I=.95$, $R M S E A=.069, S R M R=.061, A I C=132.097, E C V I=.137$.

Tam aracilık modelinin kabul edilmemesinin ardından ergenlerde alg1lanan baba davranışlarıyla akran ilişkileri arasında özerkliğin kısmi aracılığ 1 test edilmiştir. Ergenlerde algılanan baba davranışlarıla akran ilişkileri arasında özerkliğin kısmi aracı rolünü inceleyen modele ilişkin sonuçlara Şekil 8.' de yer verilmiştir.

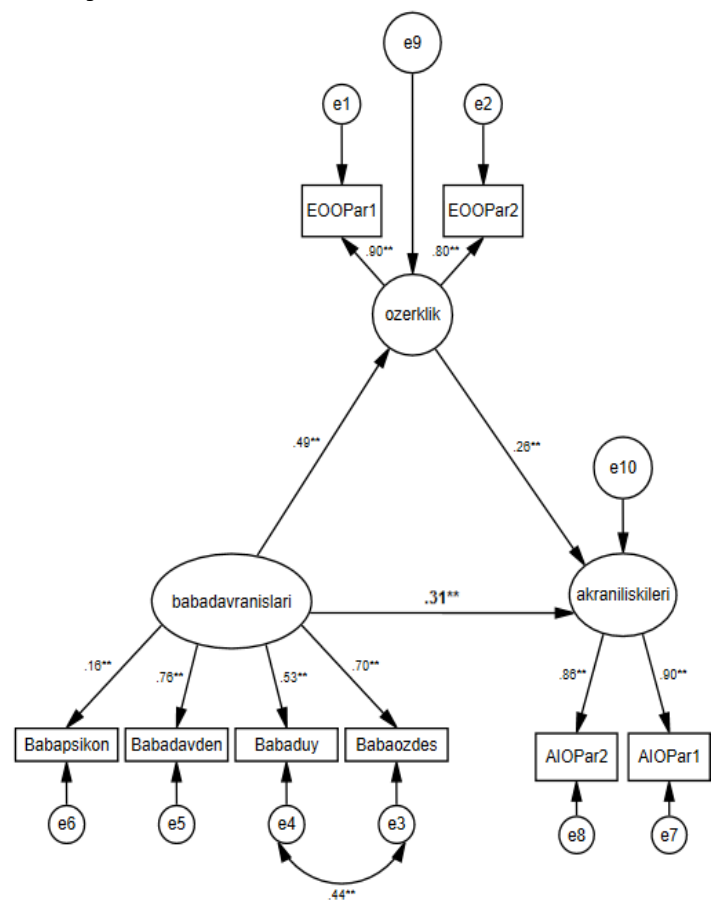

Şekil 8. Algılanan Baba Davranışlarnyla Akran İlişkileri Arasında Özerkliğin Kısmi Aracı Rolüne İlişkin Standardize Edilmiş Regresyon Katsayılarn. EÖÖ Par ergen özerklik ölçeği parselleri; AïÖ Par akran ilişkileri ölçeği parselleri; Babapsikon baba psikolojik komtrol alt boyutu; Babadavden baba davranışsal denetim alt boyutu; Babaduy baba duyarlık alt boyutu; Babaozdes baba özerklik desteği alt boyutu 
Şekil 8.' de sunulan algılanan baba davranışlarıyla akran ilişkileri arasında özerkliğin kısmi aracı rolünün incelendiği yapısal eşitlik modelinde tüm yol katsayılarının anlamlı olduğu bulunmuştur. Dolaylı etki incelendiğinde baba davranışlarının akran ilişkilerini özerklik aracılığıyla etkilediği, standardize edilmiş dolaylı etki katsayısının .12 olduğu anlaşılmaktadır. Ayrıca baba davranışlarının özerkliği yordamasına ilişkin beta $(\beta)$ katsayısının .49, özerkliğin akran ilişkilerini yordamasına ilişkin beta $(\beta)$ katsayısının .32, baba davranışlarının akran ilişkilerini yordamasına ilişkin beta $(\beta)$ katsay1sinın .31 olduğu ve bu değerlerinde anlamlı olduğu belirlenmiştir $(\mathrm{p}<.01)$.

Algılanan baba davranışlarıyla akran ilişkileri arasında özerkliğin kısmi aracı rolüne ait ölçme modelinin uyum iyiliği indeksleri şu şekilde bulunmuştur; $x^{2} / d f=3.39, \mathrm{GFI}=.98$, AGFI $=.96, \mathrm{CFI}=.98, \mathrm{NFI}=.98$, TLI= .97, RMSEA= $.050, S R M R=.035, A I C=94.251, E C V I=.098$. Elde edilen değerler modelin kabul edilebilir uyum iyiliğine sahip olduğu göstermektedir.

Test edilen aracılık modelleri incelendiğinde kısmi arac modelin tercih edilmesine karar verilmiştir. Ayrıca Baron ve Kenny' nin önerileri dikkate alındığında aracı değişkenin modele dahil edildiğinde baba davranışlarından akran ilişkilerine giden yolun .42' den .31' e düştüğü ve bu yolun halen anlamlı olması nedeniyle de kısmi aracı modelin bu araştırma kapsamında tercih edilmesi gerektiği anlaşılmıştır. Ayrıca aracılık rolünün anlamlılığını test etmek için yapılan Sobel testi sonucunda Sobel testi Z değerinin (5.36) 1.96 ' dan büyük çıkması özerkliğin baba davranışlarıyla akran ilişkileri arasında kısmi aracı role sahip olduğunu göstermektedir.

\section{Bootstrapping İşlemi}

Kısmi aracı modele ait doğrudan ya da dolaylı anlamlı olup olmadığına yönelik ek kanit sağlamak amaciyla 10.000 yeniden örnekleme yoluyla gerçekleştirilen bootstrapping işlemi sonucunda bootstrapping katsayısı ve \% 95 güven aralıkları (G.A.) alt ve üst sınırları hesaplanmış olup, sonuçlara Tablo 3.'te yer verilmiştir. 
Tablo 3. Kısmı aracı modele ait bootstrapping sonuçları

\begin{tabular}{cccc}
\hline & \multicolumn{3}{c}{ \%95 G.A. } \\
\hline Model Yolları & Katsayı & Alt Sınır & Üst Sınır \\
\hline Doğrudan etki & & & \\
\hline Baba Davranışları-Özerklik & $.49^{*}$ & $.41^{*}$ & $.56^{*}$ \\
Baba Davranışları-Akran İlişkileri & $.31^{*}$ & $.21^{*}$ & $.39^{*}$ \\
Özerklik-Akran İlişkileri & $.26^{*}$ & $.17^{*}$ & $.34^{*}$ \\
\hline Baba Davranışları-Özerklik-Akran İlişkileri & & & \\
\hline Dolaylı etki & $.12^{*}$ & $.08^{*}$ & $.17^{*}$ \\
\hline
\end{tabular}

${ }^{*} \mathrm{p}<.01$

Bootstrapping işlemi sonucunda güven aralığı alt ve üst sınırı sıfır içermediğinde incelenen etkinin anlamlı olduğu belirtilmektedir (Preacher ve Hayes, 2008). Tablo 3. incelendiğinde, modeldeki etkilerin tümünün anlamlı olduğu sonucuna varılabilir. Hem doğrudan etkilerin hem de dolaylı etkilerin bootstrapping güven aralıkları alt ve üst sınırları sıfırı kapsamamaktadır. $\mathrm{Bu}$ nedenle bootstrapping analizinde de, ergenlerde algilanan baba davranışlarıyla akran ilişkileri arasında özerkliğin kısmi aracılık rolünün olduğu söylenebilir.

\section{Tartışma}

Anne ve baba davranışları çalışmada ayrı ayrı ele alınmıştır. Anne davranışlarının tüm alt boyutları ve baba davranışlarının tüm alt boyutları ile özerklik anlamlı düzeyde ilişkili olduğu bulunmuştur. Bu bulgu alanyazında yer alan çalışmalarla tutarlı olarak ebeveynlik yaklaşımlarının özerklik ile yakından ilişkili olduğunu göstermektedir (Steinberg, 1987; Frank, Pirsch ve Wright, 1990; Hines, 1997; Beyers ve Gossens, 1999; Deslandes ve Potvin, 1999; Musaağaoğlu ve Güre, 2005). Çalışmanın bulgusuyla tutarlı olmayan bir çalışma üniversite öğrencileriyle yapılmış, özerklikle bağlantılı olan ayrışma-bireyleşme ile ebeveynlik biçimleri ilişkili bulunmamıştır (Delhaye, Kempenaers, Linkowski, Stroobants and Goossens, 2012).

Anne ve baba davranışları duyarlılı alt boyutu ile özerklik pozitif yönde anlamlı düzeyde ilişkili bulunmuştur. Ebeveynlerden algılanan sıcaklık ve ilginin özerk olmaya güdülediğiyle ilgili çalışmalar, araştırmanın bulgusuyla tutarlıdır (Frank vd., 1990; Grolnick, Ryan ve Deci, 1991; Hines, 1997). Benzer şekilde anne ve baba davranışlarının özerklik desteği boyutu ile özerklik pozitif yönde anlamlı düzeyde ilişkili bulunmuştur. Çalışmanın bulgularıyla benzer şekilde, özerklik desteği ve duyarlılığı içeren demokra- 
tik yaklaşımın anne baba tutumları içinde özerkliğe olumlu katkı sunan bir yaklaşım olarak ön plana çıkmaktadır (Yılmazer, 2007; Koç, 2019). Bunun nedeni, özerkliğin demokratik yaklaşımda ergenlerin bireyselliğinin ve kendi ayakları üzerinde durmasının desteklenmesi, sağlıklı iletişim, sıcaklık, ilgi ve bağlılı̆ın bir arada olması olarak açıklanabileceği belirtilmektedir (Grotevant ve Cooper, 1986; Frank vd., 1988; Smollar ve Youniss, 1989; Allen vd., 1994; Peterson, Bush ve Supple, 1999; Yılmaz, 2001). Bunun yanında bu çalışmanın bulgularıyla örtüşmeyen bir araştırmada özerkliği alt boyutlarına ayırarak ele almış; duygusal özerklik her iki ebeveyn için ilgi ve sıcaklıkla ilişkili değilken; davranışsal özerklik sadece anne sıcaklık ve ilgisiyle ilişkili bulunmuştur (Kayar, 2016).

Anne ve baba davranışlarının bir diğer boyutu davranışsal denetim ile özerklik arasında da pozitif anlamlı düzeyde ilişki bulunmuştur. Ergen davranışlarını izlemeyi içeren ve uygun davranışlar geliştirmek için iletişim yoluyla davranışları yapılandırma olarak ele alınan davranışsal denetim uygun ölçüde olduğunda olumlu algılanacağı belirtilmektedir. Bu boyuta yaklaşım kültürel olarak da değerlendirildiğinde, Türkiye ve Asya ülkelerinde davranışsal kontrol ebeveyn yaklaşımının çocuk ve ergenler tarafından olumsuz olarak algılanmadığı belirtilmektedir (Sümer ve Güngör, 1999; Kındap, Sayıl ve Kumru, 2008; Pomerantz ve Wang, 2009). Çalışmanın bulgusuyla tutarlı olarak ergenlerle yapılan bir çalışmada davranışsal denetim biçimlerinden izleme davranışını yüksek algılayan ergenlerin aynı zamanda annelerini yakın ve destekleyici olarak algıladığı bulunmuştur (Kındap vd., 2008). Davranışlarının izlenmesi ergen tarafından ilgi ve yakınlık olarak algılaması, kendini özerk olarak düzenlemesine olumlu katkı sunduğu düşünülmektedir. Bunun yanında ebeveyn kontrolü ile özerkliğin alt boyutu olan duygusal özerkliğin negatif ilişkili bulunduğu, bu araştırmanın bulgusuyla tutarlı olmayan bir çalışmaya rastlanmıştır (Çelik, 2015).

Anne baba davranışlarının psikolojik kontrol boyutu çocuğun anne babanın belirlediği kural ve amaçlar doğrultusunda davranması, düşünmesi için baskı yapan müdahaleci bir yaklaşımı ifade eder (Sevim, 2014). Otoriter anne baba tutumuyla bağlantılıdır. Anne davranışlarının psikolojik kontrol boyutu ile özerklik ilişkisine bakıldığında negatif ilişkili olduğu bulunmuştur. Çalışmanın bu bulgusu alanyazındaki birçok çalışmayla örtüşmektedir. Çalışmalar; sıkı denetimin, baskının, otoriter tutumun özerklik gelişimini olumsuz etkilediği yönündedir (Maccoby ve Martin, 1983; Quintana ve 
Lapsley, 1990; Grolnick vd., 1991; Steinberg, Lamborn, Dornbusch ve Darling, 1992; Özdemir, 2009; Erkmen, 2011; Rakipi, 2015; Çelik, 2015; Koç, 2019). Araştırmada baba davranışları psikolojik kontrol alt boyutu ile özerklik pozitif ilişkili bulunmuştur. Bu bulgu özerklik gelişiminde sıkı kontrolün olumsuz etkilediği araştırma sonuçlarıyla örtüşmediği görülse de alanyazında destekleyici bulgular da yer almaktadır. Özerkliğin duygusal özerklik boyutu alanyazındaki çalışmalarda ön planda olduğu görülmektedir. Duygusal özerklik bazı çalışmalarda psikolojik kontrolle pozitif ilişkili bulunmuştur (Aydın, 2000). Bunun yanında bir çalışmada, anne ve babadan algılanan sıkı denetim özerkliğin davranışsal boyutu ile negatif ilişkili; anneden algılanan sıkı denetim duygusal özerklikle ilişkili bulunmazken babadan algılanan sıkı denetim duygusal özerklik arasında pozitif yönlü bir ilişkili bulunmuştur (Kayar, 2016). Psikolojik kontrol ile özerkliğin babalarda pozitif ilişkili çıkması kültürel bağlamla da açılanabilir. Türk kültüründe, ergenin özerkliğine değer verildiği gibi bağımlılığa da yönlendirme vardır (Kağıtçıbaşı, 2005). Türk aile yapısında ergenin özerklik arayışı baba otoritesine tehdit olarak algılanabilir. Steinberg (2007) ergenlerde özerk davranışların çok az ya da çok fazla olması anne babalarda katı denetim davranışlarına neden olabileceğini belirtmektedir. Buna göre sıkı denetimin artması ergenin özerklik arayışını azaltabileceği gibi daha da artmasına da yol açabilir.

Anne baba davranışları alt boyutları ile akran ilişkisine bakıldığında hem anne hem baba davranışları tüm alt boyutlarının akran ilişkileriyle anlamlı düzeyde ilişkili olduğu görülmektedir. Alanyazında yer alan araştırmaların sonuçları incelendiğinde çalışmanın bulgusuyla örtüştüğü yani anne baba davranışlarının akran ilişkileri ile ilişkili olduğu görülmektedir (Alles-Jardel, Fourdrinier, Roux, and Schneider 2002; Cui vd., 2002; Repinski ve Zook, 2005; Soenens vd., 2007; Cook, Buehler ve Fletcher, 2012; Yaban, Sayıl ve Kındap Tepe, 2013; Tozkoparan, 2014; Bayar, 2016; Doğruyol ve Yetim, 2019). Bunun yanında anne baba tutumları ile sosyal becerilerin ilişkili olmadığına yönelik bulgu da alanyazında bulunmaktadır (Özyürek ve Özkan, 2015).

Anne baba davranışları duyarlılık, özerklik desteği ve davranışsal denetim alt boyutu hem anne hem baba için arkadaşlık ilişkileriyle pozitif ilişkili olduğu bulunmuştur. Alanyazında çalışmanın bu bulgusuyla örtüşen çok sayıda çalışma bulunmaktadır. Sıcak ve destekleyici tutum, anne baba ile 
sağlıklı ilişki, demokratik tutum olarak da ele alınan çalışmalarda bahsedilen anne baba davranışlarının, bazı çalışmalarda sosyal ilişkiler bağlamında ele alınan akran ilişkilerini olumlu etkilediği, pozitif ilişkili olduğu yönündedir (Dekovic ve Meeus,1997; Cui vd., 2002; Repinski ve Zook, 2005; Erbil, Divan ve Önder, 2006; Aktaş Özkafacı, 2012; Yaban, Sayıl ve Kındap Tepe, 2013; Karademir, 2016). Bunun yanında bu çalışmanın bulgularıyla örtüşmeyen bir çalışmada demokratik anne baba yaklaşımıyla akran ilişkilerini negatif ilişkili olduğu bulunmuş (Yenigün, 2019); bir başka çalışmada da davranışsal denetimin bir yönü olan ebeveyn izlem ile akran ilişkileri arasında ilişkiyi incelenmiş ve negatif ilişkili bulunmuştur (Karakaş, 2019).

Anne baba davranışlarının diğer bir boyutu olan psikolojik kontrol ile akran ilişkileri arasındaki ilişki incelendiğinde algılanan anne psikolojik kontrol akran ilişkileriyle negatif ilişkili; algılanan baba psikolojik kontrol ise akran ilişkileriyle pozitif ilişkili bulunmuştur. Alanyazında bulunan çalışmalar genel anlamda psikolojik kontrolün akran ilişkilerini olumsuz etkilediği yönünde olduğu görülmektedir (Soenens, Vansteenkiste, Smits, Lowet ve Goossens, 2007; Yang, 2007; Kındap vd., 2008; Kındap Tepe ve Sayll, 2012; Karademir, 2016). Bu durum anne ile ilgili bulgunun alanyazınla örtüştügünü ancak baba ile ilgili durumun örtüşmediğini göstermektedir. Bunun nedeni, babadan psikolojik kontrol algilayan ergenlerin sosyoduygusal ihtiyaçlarını yeterli düzeyde karşılayamadığından arkadaşlarına daha çok yöneldiği şeklinde düşünülebilir.

Araştırmada yer alan bir diğer konu özerklik ve akran ilişkileri ilişkisidir. Özerklik ve akran ilişkileri arasında pozitif ilişki olduğu bulunmuştur. Alanyazın incelendiğinde doğrudan özerklik ve akran ilişkilerini inceleyen bir çalışmaya rastlanmamakla birlikte değişkenlerin farklı şekillerde ele alındığı çalışmalar bulunmaktadır (Erçevik, 2014; Güney, 2017; Çiçek, 2018; Gök ve Cenkseven Önder, 2018). Akran ilişkileri; akran baskısı, sosyal destek şeklinde, özerklik; duygusal özerklik boyutuyla ve ayrışma-bireyleşme şeklinde ele alınmışır. Akran ilişkileriyle özerklik arasında pozitif ilişki olması şu şekilde açıklanabilir; akran ilişkileri ergenlik döneminde özerkliği destekleyici ve deneyimlemeye olanak sağlayıcı ortam oluşturması bakımından ergen için önemlidir. Yani ergeni, özerklik ihtiyacı akran ilişkilerine yönlendirebilmektedir. Bu çalışmanın bulgusuyla tutarlı olarak Köseoğlu ve Erçevik (2015) yaptıkları çalışmada duygusal özerklik ve arkadaşlık ilişkilerinin pozitif ilişkili olduğunu bulmuştur. Demir (2007) benzer şekilde arka- 
daşlık ilişkilerinin ergenin bireyleşme çabalarında katkı sunduğunu belirtmektedir. Allen, Bell ve Boykin (2000), aile içerisinde ergenler için sosyal gelişimin temel görevlerinden olan özerklik kurmayı öğrenmek arkadaşlık ilişkilerinin niteliklerini geliştirmenin bir öngörücüsü olarak ele almıştır. Bunun yanında çalışmanın bulgusuyla örtüşmeyen bir çalışmada ayrışmabireyleşme ile akran ilişkilerinin negatif ilişkili olduğunu bunun anlamının da; akran ilişkilerinin güçlü olmasının ayrışma bireyleşme ile ilgili daha az sorun yaşanmasını sağlayabileceği olarak değerlendirilmiştir (Çiçek, 2018).

Çalışmanın değişkenleri arasındaki ilişkiler ele alındığında tüm değişkenlerin birbiriyle anlamlı düzeyde ilişkili olduğu ve aracılık analizi yapılmasına uygun olduğu bulunmuştur. Araştırmanın amacı doğrultusunda anne baba davranışları ile akran ilişkileri arasında özerkliğin aracı rolü incelenmiştir. Anne ve baba davranışları ayrı ayrı analize alınmıştır. Yapılan analizler sonucunda hem anne davranışları hem baba davranışları ile akran ilişkileri arasında özerkliğin kısmi aracılık rolü olduğu bulgulanmıştır. $\mathrm{Bu}$ bulgu, anne baba davranışları ile akran ilişkileri arasındaki ilişkiyi tümüyle özerkliğin açıklamadığı ancak anne babanın duyarlılık, özerklik desteği, davranışsal denetim ve psikolojik kontrol gibi uygulamaları ergenin özerkliğine etki ederek akran ilişkilerinde rol üstlendiği olarak açıklanabilir. Alanyazında anne baba davranışlarının akran ilişkilerini yordadığına dair araştırma sonuçları yer almaktadır (Dekovic ve Meeus, 1997; Cui vd., 2002; Updegraff, Madden-Derdich, Estrada, Sales and Leonard, 2002; Cook vd., 2012). Bunun yanında anne baba davranışları ve akran ilişkileri arasında özerkliğin aracı rolünü doğrudan inceleyen bir çalışmaya rastlanmamakla birlikte bir çalışmada kendini kontrol edebilme olarak özkısıtlama; erkek ergenlerde anne baba biçimleri ve ailenin sosyal desteğinin hem özkısıtlama aracilığıla hem de doğrudan akran ilişkilerini etkilediği sonucuna ulaşılmıştır (Feldman ve Wentzel, 1990). Çalışmanın bulgusuyla örtüşen bir başka çalışmada da anne babanın özerklik engelleyici uygulamalarının arkadaşlık ilişkilerini olumsuz etkilediği yönündedir (Soenens ve Vansteenkiste, 2005). Benzer şekilde Hodges, Finnegan ve Perry (1999) çalışmasında anne baba çocuk ilişkisinde çarpık özerklik ilişkisinin yakın arkadaşlıklar üzerinde sorunlar oluşturacağını belirtmiştir. Yani anne baba özerkliği etkilemekte, bu durum da ergenin güven ve ilişkisellik algılarını etkilediği için akran ilişkilerinde de rol oynamaktadır. Bu araştırmanın sonuçları ve ilgili alanyazın değerlendirildiğinde kurulan modelin desteklendiği görülmüştür. Bu- 
nun yanında araştırmada özerkliğin anne baba davranışları ile akran ilişkileri arasında kısmi aracı rolü olduğu bulgusu, bu iki yapı arasında aracılık yapan başka değişkenlerin de olabileceğine işaret etmektedir.

\section{Öneriler}

Araştırma bulguları doğrultusunda ilk olarak okul psikolojik danışma uygulamalarına daha sonra, yeni yapılacak araştırmalara yönelik bir takım öneriler sıralanabilir.

Okul psikolojik danışma uygulamalarına yönelik öneriler aşağıda verilmiştir.

1. Kimlik gelişim sürecinde önemli bir rolü olan özerklik ve akran ilişkileri anne baba davranışlarıyla yakından ilişkilidir. Bu bağlamda okul psikolojik danışmanları/rehber öğretmenler, öğrencilerin sağlıklı kimlik gelişimleri için ailelere yönelik destekleyici anne babalık davranışları kazandırmak amacıyla grup rehberlik programları hazırlayabilir.

2. Anne baba davranışlarının ergenin özerklik düzeyi ve akran ilişkilerindeki etkisinden yola çıkarak anne baba davranışlarının çocuğa etkisiyle ilgili ailelere ve aynı zamanda öğretmenlere yönelik farkındalık çalışmalarına da yer verilebilir.

3. Özerklik ve akran ilişkilerinin ergenlik döneminde kazanılması gereken temel psikososyal becerilerden biri olduğu düşünüldüğünde, okul rehberlik servisi tarafından öğrencilere yönelik diğer öğretmenlerle işbirliği içinde yapılacak sosyal beceri geliştirmeye yönelik çalışmalarda özerkliği ve akran ilişkilerini destekleyici etkinliklere yer verilebilir.

4. Araştırma bulgularına göre özerklik ve akran ilişkilerinin bağlantısı düşünüldüğünde suç işleme, madde kullanımı gibi riskli davranışlar ile ruh sağlığı üzerindeki etkileri göz önünde bulundurularak özerklik düzeyi düşük, akran ilişkileri olumsuz olan öğrencilere yönelik okul rehberlik servisi tarafından müdahale programları; diğer öğrencilere yönelik ise önleyici ve gelişimsel programlar hazırlanabilir.

5. Ergenlik döneminin önemli bir parçası ve ergenliğin gelişim görevlerinden olan akran ilişkileri araştırma bulguları doğrultusunda değerlendirildiğinde rehber öğretmenlerin ergenlerin yaşıtlarıyla olan ilişkisine yönelik yaptı̆̆ çalışmalarda işlevsellik ve etkililik açısından akran ilişki- 
lerinde rol oynayan özerklik ve anne baba davranışları gibi faktörleri de göz önünde bulundurabilir.

Araştırma bulguları doğrultusunda yeni yapılacak çalışmalara yönelik öneriler aşağıda verilmiştir.

1. Araştırmada anne baba davranışları ayrı ayrı incelenmiş olup anne baba davranışları ile akran ilişkileri arasında özerkliğin kısmi aracı rolü olduğu bulunmuştur. Ergenlerde anne baba davranışları ve akran ilişkileri arasındaki bağın ortaya konması açısından aracı değişken olarak; kişilik özellikleri, benlik saygısı, temel psikolojik ihtiyaçlar, bağlanma stilleri gibi aracı değişkenler çalışılabilir.

2. Alanyazında ergenlerin özerklik düzeyini belirlemek amacıyla kullanılan ölçekler sınırlıdır. Bu nedenle ergenlerde özerklik düzeyine ilişkin ölçek çalışmaları yapılabilir.

3. Anne baba davranışlarının algılanması, özerklik düzeyi ya da akran ilişkileri kız ve erkek ergenler için farklılaşabilir. Bu yüzden araştırmada ele alınan değişkenler arasındaki ilişki cinsiyet değişkeni dikkate alınarak incelenebilir.

4. Araştırma bulguları Gaziantep ilinin Şehitkamil ilçesinde fen, Anadolu ve meslek liselerinde öğrenim gören öğrencilerden elde edilmiştir. Farklı yaş grubu, okul düzeyi vb. göz önünde bulundurularak yapılacak diğer çalışmalarla bulgular karşılaştırılabilir.

5. Araştırma bulguları anne baba davranışları, özerklik ve akran ilişkilerinin ilişkisine yönelik kesitsel bir çalışma olduğundan söz konusu ilişkilerin ergenlik dönemi öncesinde, ergenlik dönemi boyunca ve ergenlik dönemi sonrasındaki değişiminin ve gelişiminin daha iyi anlaşılması açısından boylamsal bir çalışma yapılabilir. 


\title{
EXTENDED ABSTRACT
}

\section{The Mediating Role Of Autonomy Between Perceived Parent Behavior And Peer Relationships In Adolescents}

\author{
Fatma Akın Gökalp - Mehmet Murat \\ Şehit Ercan Hirçın Middle School, Gaziantep University
}

Adolescence is a period of physical, social and cognitive maturation (Gander and Gardiner, 2010). Behavioral patterns formed by the individual during adolescence, the adolescent's level of self-acceptance, parent and friendship relationships, and healthy autonomy is important for the adolescent. Parents with mental and social skills of adolescents in the tops of the environmental factors that play a role in gaining awareness of their emotional response in interpersonal relations but to adolescent period to begin differentiation child and parent priorities and perspectives taste. Adolescents who are not experienced in each subject want to be independent from them, but on the other hand, they need to be understood and supported by them (Gültekin and Baran, 2007; Atalay, 2018). However, in adolescence, interaction with peers gradually increases, and the approval and acceptance by the peer group begins to become stronger (Kaner, 2000). Adolescents spend most of their energy on making friends.

Parental behaviors are one of the most fundamental factors affecting the socialization of the individual (Kulaksizoğlu, 2004; Damarl, 2006). When the literature is examined, parents' behaviors, which are thought to affect peer relationships, are emphasized (Curtner- Smith and MacKinnon , 1994; Ladd and Ladd , 1998; Akgün, 2005; Şirvanlı Özen, 2006; Soenens, Vansteenkiste, Smits, Lowet andGoossens, 2007; Totan and Yöntem,2007;Cook , Buehler, and Fletcher , 2012; Yaban,Sayll, and Kındap Tepe, 2013). Parental behaviors discussed in this study; Being sensitive / caring constitutes behavioral control, psychological control (Sevim, 2014) and support for autonomy added later (Silk, Morris, Kanaya, Steinberg , 2003). Sensitivity, support and closeness from parents; effective control exercised by 
parents in line with behavioral control, rules and principles; psychological control involves mothers and fathers using an oppressive and intrusive control process; Support for autonomy refers to the support of the parents of the decisions taken by the adolescent as a result of their own will (Sevim, 2014).

Autonomy is an important skill to be acquired in transition to adulthood while interacting with the adolescent's environment (Tung and Dhillon , 2006; Steinberg , 2007; Lynch, 2013). Autonomy is considered as the individual's independence from other individuals, taking responsibility for his own actions and decisions, and a sense of competence (Noom, Dekovic, Meeus, 2001). Adolescence, physical, cognitive, social changes that occur with new rights and responsibilities, accelerate the development of autonomy is make (and very Ozdemir, 2011). The importance of friendship relations of adolescents by moving away from their parents is related to the need for autonomy. According to the perception of parents and adolescents, in a study examining the level of authority of parents over some choices of the adolescent (Smetana , 2008), it was found that both parents and adolescents were not authorized to impose their choices by force, in contrast to moral, religious and educational fields where parents were perceived to be more authorized. it has been revealed that they perceive them as areas. This situation can be evaluated as a reflection of the autonomy of the adolescent.

Parental behavior, peer relationships and autonomy, which are the variables of this study, constitute three important components of the adolescent period. When the literature is examined, it is seen that these structures are connected with each other. In adolescence, along with many changes, increased independence, change in parental behavior and an orientation to peer relationships are observed. Considering the important effects of relations with peers, which have an important place in adolescence period studies and are also among the developmental tasks of adolescence, on social development, individualization, identity formation and gaining an independent place in society; the importance of examining the structures that affect peer relationships is emerging. With the need for independence, adolescents approach their peers from their parents. It is thought that parental behaviors have an effect on peer relationships, however, autonomy, which is an important skill that matures in adolescence, has an important role on the mentioned parent-peer relationship. The aim of the study is to examine 
the mediating role of autonomy between perceived parental behaviors and peer relationships in adolescents.

This research, which examines the relationships between research variables within the framework of the structural equation model, is a descriptive study in the form of a relational survey model. Research participants, the province of Gaziantep Şehitkamil science district, Anatolian studying in vocational schools and 444 'ü (46.1\%) male and 519'u (53.9\%) constitute a total of 963 female adolescents. In the collection of the research data, 'Peer Relations Scale (AIÖ)', ' Leuven Perceived Parenthood / Adolescent Version Scale (LAPS / e)', 'Adolescent Autonomy Scale (EÖÖ) ' and 'Personal Information Form' prepared by the researcher were used.

The analysis of the data collected within the scope of the research was carried out using the SPSS 21 package program and the AMOS (Analysis of Moment Structures) 22.0 program. Whether there is a mediator role of autonomy between perceived parental behaviors and peer relationships in adolescents was analyzed using a structural equation model (SEM) in separate models for mothers and fathers. In addition, in this study, the parceling method suggested by Bandalos (2002) was used to create latent variables of adolescent autonomy (EÖÖ Par 1, EÖÖ Par 2) and friendship relations (AİÖ Par 1, AIÖ Par 2) to improve fit indices in the models examined. The suggestions of Baron and Kenny (1986) were taken into account in order to determine whether autonomy had a mediating role between parental behavior and peer relationships.

Considering the relationships between the variables of the study, it was found that all variables were significantly correlated with each other and suitable for mediation analysis. In line with the purpose of the study, the mediating role of autonomy between parental behavior and peer relationships was examined. Mother and father behaviors were analyzed separately. Studies in the literature show that parental behaviors are related to peer relationships; It is observed that adolescents who grow up in families with sensitive, warm and supportive parents have positive peer relationships, while oppressive, authoritarian and high control parental behaviors have a negative role in their peer relationships. Besides, in the literature, the autonomy supporting behaviors of the parents are positive with the peer relationships of the adolescent; nag parents with adolescent peer relationships autonomy inhibitory action if a is said to be associated. As a result of the anal- 
ysis, it was found that autonomy had a partial mediating role between both mother and father behaviors and peer relations. As further evidence of the significance of the part through Bootstrapping and Sobel test was usage. As a result of both analyzes, it was concluded that partial mediation was significant. This finding can be explained as that autonomy does not completely explain the relationship between parental behavior and peer relations, but parents' practices such as sensitivity, autonomy support, behavioral control, and psychological control play a role in peer relationships by affecting the autonomy of the adolescent. There are research results showing that parental behaviors predict peer relationships in the literature (Dekovic and Meeus , 1997; Cui et al ., 2002; Updegraff et al., 2002; Cook et al., 2012). In addition to this, although there is no study that directly examines the mediating role of autonomy between parental behavior and peer relationships, in one study self- restraint as self-control; It was concluded that in male adolescents, parenting styles and family social support both directly affect peer relationships through self-restraint (Feldman and Wentzel , 1990). Another study that coincides with the findings of the study is that parents' practices that prevent autonomy negatively affect friendship relations (Soenens and Vansteenkiste, 2005). Similarly, Hodges, Finnegan, and Perry (1999) stated that the distorted autonomy relationship in the parent-child relationship will create problems on close friendships. In other words, parents affect autonomy, which also plays a role in peer relationships as this affects the adolescent's perceptions of trust and rationality. In addition, the finding that autonomy has a partial mediating role between parental behavior and peer relationships in the study indicates that there may be other variables that mediate between these two structures.

\section{Kaynakça / References}

Acun-Kapıkıran, N. (2011). Focus on positive and negative information as the mediator the relationship between empathy tendency guilty and psychological well-being in university students. Educational Sciences: Theory and Practice, 11(3), 1141-1147.

Akgün, S. (2005). Akran zorbalı̆ğmn anne-baba tutumlar ve anne-baba ergen ilişkisi açısından incelenmesi. Yayınlanmamış yüksek lisans tezi. Hacettepe Üniversitesi Sosyal Bilimler Enstitüsü, Ankara. 
Aktaş Özkafacl, A. (2012). Annenin çocuk yetiştirme tutumu ile çocuğun sosyal beceri düzeyi arasındaki ilişkinin incelenmesi. Yayınlanmamış yüksek lisans tezi. İstanbul Ar-El Üniversitesi Sosyal Bilimler Enstitüsü, İstanbul.

Allen, J., Bell, K. ve Boykin, K. A. (2000). Autonomy in discussions vs. autonomy in decision-making as predictors of developing close friendship competence. In biennial meeting of the Society for Research on Adolescence, Chicago, IL.

Allen, J. P., Hauser, S. T., Bell, K. L. ve O'Connor,T. (1994). Longitudinal assessment of autonomy and relatedness in adolescent-family interactions as predictors of adolescent ego development and self esteem. Child Development, 65, 179194.

Alles-Jardel, M., Fourdrinier, C., Roux, A. ve Schneider, B. H. (2002). Parents' structuring of children's daily lives in relation to the quality and stability of children's friendships. International Journal of Psychology, 37(2), 65-73.

Anderson, J. C. ve Gerbing, D. W. (1988). Structural equation modeling in practice: A review and recommended two-step approach. Psychological Bulletin, 103(3), 411- 423.

Atalay, D. (2018). Ergenlerin anne-baba tutum algist ve arkadaşlı ilişkileri ile duygu düzenlemelerinin incelenmesi. Yayınlanmamış yüksek lisans tezi. Karabük Üniversitesi Sağlık Bilimleri Enstitüsü, Karabük.

Aydın, G. (2000). Autonomy development in adolescence. Yayınlanmamış yüksek lisans tezi. Orta Doğu Teknik Üniversitesi, Ankara.

Bachman, L. F. (2004). Statistical analyses for language assessment. California: Cambridge University Press.

Bandalos, D. L. (2002). The effects of item parceling on goodness-of-fit and parameter estimate bias in structural equation modeling. Structural Equation Modeling, 9(1), 78-102.

Bandura, A. (1977). Social learning theory. New Jersey: Prentice Hall, In.

Baron, R. M. ve Kenny, D. A. (1986). The moderator-mediator variable distinction in social psychological research: Conceptual, strategic, and statistical considerations. Journal of Personality and Social Psychology, 51(6), 1173.

Bayar, Y. (2016). Ergen ve anne bildirimine göre ebeveyn akran yönetiminin öncülleri ve akran ilişkileri açısından sonuçları. Yayınlanmamıs doktora tezi. Hacettepe Üniversitesi Sosyal Bilimler Enstitüsü, Ankara.

Bayraktar, F. (2007). Olumlu ergen gelişiminde ebeveyn/akran ilişkilerinin önemi. Çocuk ve Gençlik Ruh Sağ̆lı̆̆ Dergisi, 14 (3),157-166. 
Beyers, W. ve Goossens, L. (1999). Emotional autonomy, psychosocial adjustment and parenting: interactions, moderating and mediating effects. Journal of Adolescence, 22, 753-769.

Calp, Ş., Karaman, E. R. ve Çavuşoğlu, F. (2018). İlkokulda akran ilişkileri: Farklı başarı düzeyindeki dördüncü sınıf öğrencileri arkadaş özerklik desteği hissediyor mu? Kalem Eğitim ve İnsan Bilimleri Dergisi, 8(1), 237-265.

Cook, E. C., Buehler, C. ve Fletcher, A. C. (2012). A process model of parenting and adolescents' friendship competence. Social Development, 21(3), 461-481.

Cui, M., Conger, R. D., Bryant, C. M. ve Elder, G. H. (2002). Parental behavior and the quality of adolescent friendships: A social-contexual perspective. Journal of Marriage and Family, 64, 676-689.

Curtner-Smith, M. E. ve MacKinnon-Lewis, C. E. (1994). Family process effects on adolescent males' susceptibility to antisocial peer pressure. Family Relations, 43(4), 462-468.

Çelik, E. G. (2015). Algilanan ebeveyn kontrolü ile ergen iyi oluşu arasındaki ilişkide duygusal özerklik ve empatinin aracı rolü. Yayınlanmamış yüksek lisans tezi. Ankara Üniversitesi Eğitim Bilimleri Enstitüsü, Ankara.

Çelik, H. E. ve Yılmaz, V. (2016). LISREL 9.1 ile yapısal eşitlik modellemesi: Temel kavramlar-uygulamalar-programlama (3. Baskı). Ankara: Anı Yayıncilk.

Çiçek, İ. (2018). Ergenlerin kişilik özellikleri ile aynışma bireyleşme arasındaki ilişkide akran ilişkilerinin aracı etkisi. Yayınlanmamıs doktora tezi. İstanbul Üniversitesi Eğitim Bilimleri Enstitüsü, İstanbul.

Damarl, Ö. (2006). Ergenlerde toplumsal cinsiyet rolleri, bağlanma stilleri ve benlik kauramı arasındaki ilişkiler. Yayınlanmamış yüksek lisans tezi. Ankara Üniversitesi Sosyal Bilimler Enstitüsü, Ankara.

Dekovic, M. ve Meeus, W. (1997). Peer relations in adolescence: effects of parenting and adolescents' self-concept. Journal of Adolescence, 20(2), 163-176.

Delhaye, M., Kempenaers, C., Linkowski, P., Stroobants, R. ve Goossens, L. (2012). Perceived parenting and separation-individuation in Belgian college students: Associations with emotional adjusment. The Journal of Psychology, 146(4), 353-370.

Demir, İ. (2007). Gençlerin kimlik yaplarn: Farkl yerellikler ekseninde nitel bir inceleme. Yayımlanmamış doktora tezi. İstanbul Üniversitesi Sosyal Bilimler Enstitüsü, İstanbul.

Derman, O. (2008). Ergenlerde psikososyal gelişim. Adolesan Sağhlğı II Sempozyum Dizisi, 63, 19-21. 
Deslandes, R. ve Potvin, P. (1999). 'Autonomy, parenting, parental involvement in schooling and school achievement: perception of Quebec adolescents', Paper presented at the Annual Conference of the American Educational Research Association (Montreal, Quebec, Canada). Available at: http://files.eric.ed.gov/fulltext/ED430697.pdf

Doğruyol, S. ve Yetim, Ü. (2019). Ebeveyne bağlanma, algilanan anne/baba tutumu ıle akran ılişkileri arasındaki llişkide benlik saygısının araclık rolü. Nesne, 7(14), 34-51. Doi: 10.7816/nesne-07-14-03

Erbil, N., Divan, Z. ve Önder, P. (2006). Ergenlerin benlik saygisına ailelerinin tutum ve davranışlarının etkisi. Aile ve Toplum Dergisi, 3(10), 7-15.

Erçevik, A. (2014). Lise öğrencilerinin duygusal özerlik ve sosyal destek düzeyleri arasındaki ılişkinin ıncelenmesi. Yayınlanmamış yüksek lisans tezi. İstanbul Üniversitesi Eğitim Bilimleri Enstitüsü, İstanbul.

Erkmen, E., (2011). Özerkliği destekleyici ve kontrol edici ebeveynlikle bağlantil ebeveyn özellikleri ve ergenin uyumu arasındaki ilişkiler. Yayınlanmamış yüksek lisans tezi. Hacettepe Üniversitesi Sosyal Bilimler Enstitüsü, Ankara.

Feldman, S. S. ve Wentzel, K. R. (1990). The relationship between parenting styles, sons' self-restraint, and peer relations in early adolescence. The Journal of Early Adolescence, 10(4), 439-454.

Frank, S. J., Avery, C. B. ve Laman, M. S. (1988). Young adults' perceptions in their relationships with their parents: individual differences in connectedness, competence and emotional autonomy. Developmental Psychology, 24, 729737.

Frank, S. J., Pirsch, L. A. ve Wright, V. C. (1990). Late adolescents perceptions of their relationships with their parents: Relationships among deidealization, autonomy, relatedness, insecurity and implications for adolescent adjustment and ego identity status. Journal of Youth and Adolescence, 29, 571588.

Gander, M. J. ve Gardiner, H. W. (2010). Çocuk ve ergen gelişimi. (A. Dönmez, B. Onur, N. Çelen, Çev.) Ankara: İmge Kitabevi Yayınları.

George, D. ve Mallery, P. (2003). SPSS for Windows step by step: answers to selected exercises. A Simple Guide and Reference, 63, 1461-1470.

Gladding, S. T. (2011). Aile terapisi: Tarihi, kuram ve uygulamalarn (5.baskı). (İ. Keklik, İ. Yıldırım, Çev. Ed.) Ankara: Türk Psikolojik Danışma ve Rehberlik Derneği Yayınları. 
Golonka, M. M. (2013). Keeping in touch: Relationships between parenting style, parentchild electronic communication, and the developing autonomy and adjustment of college students. Yayınlanmamış doktora tezi. Duke University, Durham NC.

Gök, F. ve Cenkseven Önder, F. (2018). Lise öğrencilerinde akran zorbaliğina maruz kalma: temel psikolojik ihtiyaçlar ve anne-babaya duygusal erişilebilirlik. Mersin Üniversitesi Eğitim Fakültesi Dergisi, 14(2), 635-652. DOI: 10.17860.

Gray, M. R., ve Steinberg, L. (1999). Unpacking authoritative parenting: Reassessing a multidimensional construct. Journal of Marriage and the Family, 61, 574-587.

Grolnick, W., Ryan, R. ve Deci, E. (1991). Inner resources for school achievement: Motivational mediators of children's perceptions of their parents. Journal of Educational Psychology, 83, 508-517.

Grotevant, H. D. ve Cooper, C. R. (1986). Individuation in family relationships: A perspective on individual differences in the development of identity and role taking skill in adolescence. Human Development, 29, 82-100.

Gültekin, G. ve Baran G. (2007). The self-perception of deliquent children in Turkey. Pakistan Journal of Social Science, 4(2), 224-229.

Güney, M. A. (2017). Ergenlerde duygusal özerklik, sosyal destek ve öznel ryi oluş arasındaki ılişkinin ıncelenmesi. Yayınlanmamış yüksek lisans tezi. Necmettin Erbakan Üniversitesi Eğitim Bilimleri Enstitüsü, Konya.

Hines, A. (1997). Divorce-related transitions, adolescent development and the role of the parent child relationships: A review of the literature. Journal of Marriage and the Family, 59, 375-388.

Hodges, E. V., Finnegan, R. A. ve Perry, D. G. (1999). Skewed autonomy-relatedness in preadolescents' conceptions of their relationships with mother, father, and best friend. Developmental Psychology, 35(3), 737-748.

Kagitçıbası, Ç. (2005). Autonomy and relatedness in cultural context: Implication for self and family. Journal of Cross Cultural Psychology, 36, 403- 422.

Kaner, S. (2000). Akran ilişkileri ölçeği ve akran sapması ölçeği geliştirme çalışması. Ankara Üniversitesi Eğitim Bilimleri Fakültesi Dergisi. 33(1-2), 67-75.

Karademir, A. (2016). Algilanan anne tutumlan ile zorbalı mă̆duriyet ilişkisinde ontolojik iyi oluşun aracılık rolü. Yayınlanmamış yüksek lisans tezi. İstanbul Arel Üniversitesi Sosyal Bilimler Enstitüsü, İstanbul.

Karakaş, H. (2019). Ergenlerin algıladıklan ebeveyn izlemesi ve akran ilişkilerinin incelenmesi. Yayınlanmamış yüksek lisans tezi. Bolu Abant İzzet Baysal Üniversitesi Eğitim Bilimleri Enstitüsü, Bolu. 
Karasu, H. (2013). Ergenlerde özerklĭgin yordayıcısı olarak bağlanma stilleri ve proaktif kişilik yaplarmın incelenmesi. Yayınlanmamış yüksek lisans tezi. Gaziosmanpaşa Üniversitesi Eğitim Bilimleri Enstitüsü, Tokat.

Kayar, O. (2016). Ergenlerde algllanan ebeveynlik stilleri, özerklik ve yaratıcllk arasindaki ilişkiler. Yayınlanmamış yüksek lisans tezi. Abant İzzet Baysal Üniversitesi Sosyal Bilimler Enstitüsü, Bolu.

Kındap, Y., Sayıl, M. ve Kumru, A. (2008). Anneden algılanan kontrolün niteliği ıle ergenin psikososyal uyumu ve arkadaşlıkları arasındaki ılişkiler: Benlik değerinin aracı rolü. Türk Psikoloji Dergisi, 23(61), 92-107.

Kındap Tepe, Y. ve Sayll, M. (2012). Ebeveyn kontrolü ve ergenin sosyal ışlevselliği arasındaki bağlantıda 1lişkisel saldırganlı̆̆ın aracı rolü. Türk Psikoloji Dergisi, 27(70), 119-132.

Kline, R. B. (2015). Principles and practice of structural equation modeling. New York: Guilford publications.

Kocayörük, E. (2012). Öz-belirleme kuramı açısından ergenlerin anne baba algısı ile duyuşsal iyi oluşları arasındaki ilişki. Türk Psikolojik Danışma ve Rehberlik Dergisi, 4(37), 24-37.

Koç, F. (2019). Ergenlerde anne baba tutumlar ile duygusal özerklik arasındaki ilişkinin çeşitli değişkenlere göre incelenmesi: Düzce ili örneği. Yayınlanmamış yüksek lisans tezi. Marmara Üniversitesi Eğitim Bilimleri Enstitüsü, İstanbul.

Köseoğlu, S. A. ve Erçevik, A. (2015). Lise öğrencilerinin duygusal özerklik ve sosyal destek düzeyleri arasındaki ilişkinin incelenmesi. Abant İzzet Baysal Üniversitesi Ĕ̆itim Fakültesi Dergisi, 15 (2), 198-216.

Kulaksızoğlu, A. (2004). Ergenlik psikolojisi (6. Baskı). İstanbul: Remzi Kitabevi.

Ladd, G. W. ve Ladd, B.K. (1998). Parenting behaviors and parent-child relationships: Correlates of peer victimization in kindergarten? Developmental Psychology, 34(6), 1450-1458.

Lynch, M. F. (2013). Attachment, autonomy, and emotional reliance: A multilevel model. Journal of Counseling and Development, 91, 301-314.

Maccoby, E. E. ve Martin, J. A. (1983). Socialization in the context of the family: 111 parent - child interaction. P. H. Mussen and E. M. Hetherington (Ed.), Handbook of Child Psychology: Socialization. Personality and Social Development. New York: Wiley.

McElhaney, K. B. ve Allen, J. P. (2001). Autonomy andadolescent social functioning: The moderating effect of risk. Child Development, 72(1), 220-235. 
Morsünbül, Ü. (2012). Özerklik ve ruh sağllğına etkisi. Psikiyatride Güncel Yaklaşımlar-Current Approaches in Psychiatry, 4(2), 260-278. Doi:10.5455/cap.20120416

Musaağaoğlu, C. (2004). Ergenlik sürecinde özerkliğin gelişimi ile algilanan ana-baba tutumlan arasındaki ilişkiler. Yayınlanmamış yüksek lisans tezi. Hacettepe Üniversitesi Sosyal Bilimler Enstitüsü, Ankara.

Musaağaoğlu, C. ve Güre, A. (2005). Ergenlerde davranışsal özerklik ile algilanan ana-baba tutumları arasındaki ilişkiler. Türk Psikoloji Dergisi, 20(55), 79-98.

Noom, M. (1999). Adolescent autonomy: Characteristics and correlates. Eburon Publishers.

Noom, M. J., Dekovic, M. ve Meeus, W. (2001). Conceptual analysis and measurement of adolescent autonomy. Journal of Youth and Adolescence, 30, $577-595$.

Öngen, D. (2004). Özerklik kazanma sürecinde ergen-anne ile ergen-baba ilişkileri arasındaki farklılıklar. Eğitini ve Bilim, 29(131), 3-13.

Özakkaş, T. (2015). Bütüncül psikoterapi (7. Baskı).İstanbul: Litera Yayıncllk.

Özdemir, Y. (2009). Ergenlik döneminde benlik kurgusu gelişiminin kültür ve aile bağlaminda incelenmesi. Yayınlanmamıs doktora tezi. Ankara Universitesi Sosyal Bilimler Enstitüsü, Ankara.

Özdemir, Y. ve Çok, F. (2011). Ergenlikte özerklik gelişimi. Türk Psikolojik Danışma ve Rehberlik Dergisi, 4(36), 152-164.

Özyürek, A. ve Özkan, İ. (2015). Ergenlerin algiladıkları anne baba tutumları ile sosyal beceri düzeyleri arasındaki ilişkinin incelenmesi. International Journal of Science Culture and Sport (IntJSCS), 73-88. Doi: 10.14486/IJSCS259

Peterson, G.W., Bush, K.R. ve Supple, A. (1999). Predicting adolescent autonomy from parents: Relationship, connectedness and restrictiveness. Sociological Inquiry, 69(3), 431-457.

Pomerantz, E. M. ve Wang, Q. (2009). The role of parental control in children's development in western and East Asian countries. Current Directions in Psychological Science, 18, 285-289.

Preacher, K. J. ve Hayes, A. (2008). Asymptotic and resampling strategies for assessing and comparing indirect effects in multiple mediator models. Behavior Research Methods, 40(3), 879-891.

Quintana, S. ve Lapsley, D. (1990). Reapproachment in late adolescent seperationindividuation: A structural equations approach. Journal of Adolescence, 13, 371-385. 
Rakipi, S. (2015). Parenting styles: Their impact on adolescent separation and college adjustment. Yayınlanmamış doktora tezi. Capella University, Minneapolis.

Repinski, D. J. ve Zook. J.M. (2005). Three meausures of closeness in adolescents relationships with parents and friends: Variations and developmental significance. Personal Relationships. 12, 79-102.

Santrock, J. W. (2017). Ergenlik (14. Baskı). (D. M. Siyez, Çev.). Ankara: Nobel Yayincilik.

Sevim, S. (2014). Leuven Algilanan Ana Babalık Ölçeği ergen ve ana baba sürümlerinin uyarlanması. Düşünen Adam, 27, 291-300.

Silk, J. S., Morris, A. S., Kanaya, T. ve Steinberg, L. (2003). Psychological control and autonomy granting: Opposite ends of a continuum or distinct constructs? Journal of Research on Adolescence, 13(1), 113-128.

Smetana, J. G. (1995). Parenting styles and beliefs about parental authority. New Directions for Child Development: Beliefs About Parenting, Origins And Developmental Implications. Judith, G. Smetana (Ed.) California: Jassey- Boss Publishers.

Smetana, J. G. (2008). "It's 10 o'clock: Do you know where your children are?" Recent advances in understanding parental monitoring and adolescents' information management. Child Development Perspectives, 2(1), 19-25.

Smollar, J. ve Younnis, J. (1989). Transformations in adolescent's perceptions of parents. International Journal of Behavior, 12, 71-84.

Soenens, B. ve Vansteenkiste, M. (2005). Antecedents and outcomes of selfdetermination in 3 life domains: The role of parents' and teachers autonomy support. Journal of Youth and Adolescence. 34(6), 589-604.

Soenens, B., Vaansteenkiste, M., Smits, I, Lowet, K. ve Goossens, L. (2007). The role of intrusive parenting in the relationship between peer management strategies and peer affiliation. Journal of Applied Developmental Psychology, 28(3), 239-249.

Steinberg, L. (1987). Single parents, step parents and the susceptibility of adolescents to antisocial peer pressure. Child Development, 58, 269-275.

Steinberg, L., Lamborn, S.M., Dornbusch, S. ve Darling, N. (1992). Impact of parenting practices on adolescent achievement: Authoritative parenting, school involment, and encouragement to succeed. Child Development, 63, 1266-1281.

Steinberg, S. (2007). Ergenlik. (F. Çok, Çev.). Ankara: İmge Kitabevi.

Sümer, N. ve Güngör, D. (1999). Çocuk yetiştirme stillerinin bağlanma stilleri, benlik değerlendirmeleri ve yakın llişkiler üzerindeki etkisi. Türk Psikoloji Dergisi, 14(44), 35-63. 
Şimşek, Ö. M. (2007). Yapısal eşitlik modellemesine giriş temel ilkeler ve LISREL uygulamalar. Ankara: Ekinoks Yayıncilk.

Şirvanlı-Özen, D. (2006). Ergenlerde akran zorbalı̆ğına maruz kalmanın yaş, çocuk yetiştirme stilleri ve benlik imgesi ile ilişkisi. Türk Psikoloji Dergisi, 21(58), 7794.

Totan, T. ve Yöndem, Z. D. (2007). Ergenlerde zorbalığın anne, baba ve akran ilişkileri açısından incelenmesi. Ege Üniversitesi Eğitim Fakültesi Dergisi, 8(2), 53-68.

Tozkoparan, S., (2014). Ö̈̆renci algrstna göre aileden alinan sosyal destek, anne-baba tutumu ve akran ilişkileri "Özel çevre ortaokulu öğrencileri üzerinde ilişkisel bir tarama". Yayınlanmamış yüksek lisans tezi. Maltepe Üniversitesi Sosyal Bilimler Enstitüsü, İstanbul.

Tung, S. ve Dhillon, R. (2006). Emotional autonomy in relation to family enviroment: A gender perspective. Journal of The Indian Academy of Applied Psychology, 32(3), 201-212.

Updegraff, K. A., Madden-Derdich, D. A., Estrada, A. U., Sales, L. J. ve Leonard, S. A. (2002). Young adolescents' experiences with parents and friends: Exploring the connections. Family Relations, 51, 72-80.

Yaban, E. H., Sayll, M. ve Kindap Tepe, Y. (2013). Erkek ergenlerde anne babadan algılanan destek ile akran zorbalığı arasındaki ilişkide arkadaşık niteliğinin rolü. Türk Psikoloji Dergisi, 28 (71), 20-32.

Yang, Z. (2007). The impact of parenting on susceptibility to peer influence: Role of selfconcept and culture. Yayınlanmamış yüksek lisans tezi. Concordia University, Montreal.

Yenigün, F. (2019). Ergenlik döneminde alglanan anne baba tutumlarmin bireyin ruhsal durumlar ve akran ilişkileri üzerindeki etkileri. Yayınlanmamış yüksek lisans tezi. Üsküdar Üniversitesi Sosyal Bilimler Enstitüsü, İstanbul.

Yılmaz, A. (2001). Eşler arasındaki uyum, anne baba tutumları ve benlik algısı arasındaki ilişkilerin gelişimsel olarak incelenmesi. Türk Psikoloji Dergisi,16, $1-20$.

Yllmazer, Y. (2007). Anne-baba tutumlan ile ilköğretim ikinci kademe öğrencilerinin okul başarnsı ve özerkliklerinin gelişimi arasindaki ilişkinin incelenmesi. Yayınlanmamıs yüksek lisans tezi. Hacettepe Üniversitesi Sağlık Bilimleri Enstitüsü, Ankara.

Yörükoğlu, A. (2019). Gençlik çağı/ Ruh sağhlğı ve ruhsal sorunlar (15. Bask1). İstanbul: Özgür yayınları. 
Yurttaş A. (2010). İlköğretim ikinci kademe öğrencilerinin zorbalı eğilimleri ile algıladıllarn anne baba tutumları arasindaki ilişkinin incelenmesi. Yayınlanmamış yüksek lisans tezi. Yeditepe Üniversitesi Sosyal Bilimler Enstitüsü, İstanbul.

\section{Kaynakça Bilgisi / Citation Information}

Akın Gökalp, F. ve Murat, M. (2020). Ergenlerde algılanan anne baba davranışlarıyla akran ilişkileri arasında özerkliğin aracı rolü. OPUS-Uluslararası Toplum Araştırmaları Dergisi, 16(Eğitim ve Toplum Özel Say1s1), 5841-5883. DOI: 10.26466/opus.804045 